\title{
Michał Wyszyński
}

\section{Metus reverentialis w rzymskim i kanonicznym prawie małżeńskim}

Prawo Kanoniczne : kwartalnik prawno-historyczny 4/1-4, 223-272

1961

Artykuł został zdigitalizowany i opracowany do udostępnienia w internecie przez Muzeum Historii Polski w ramach prac podejmowanych na rzecz zapewnienia otwartego, powszechnego i trwałego dostępu do polskiego dorobku naukowego i kulturalnego. Artykuł jest umieszczony w kolekcji cyfrowej bazhum.muzhp.pl, gromadzącej zawartość polskich czasopism humanistycznych i społecznych.

Tekst jest udostępniony do wykorzystania w ramach dozwolonego użytku. 


\section{METUS REVERENTIALIS \\ W RZYMSKIM I KANONICZNYM PRAWIE MAEZENSKIM}

Gdy swego czasu po napisaniu dwóch pierwszych prac, jednej w zwyczajnym seminarium prof. Balzera, a drugiej w ,wyższym" seminarium prof. Abrahama ${ }^{1}$ - jako jednoroczny stypendysta wyjeżdżałem do Rzymu na praktykę w Rocie i pogłębienie studiów prawniczych, zapytałem prof. Abrahama, na który dział baidań mam zwrócić szczególniejszą uwagę, otrzymałem taką odpowiedź: „Radzę zając się nieopracowanym jeszcze od strony prawnohistorycznej zagadnieniem wplywu bojaźni na zawarcie małżeństwa rzymskiego i kanoniczneg:o".

Z rozmysłu przytoczyłem to osobiste zdarzenie, bo pragnę wyjaśnić, dlaczego na uczczenie 100 rocznicy urodzin prof. Abrahama wybrałem właśnie ten a nie inny temat. Otóż praca niniejsza jest $z$ rzędu piątą $z$ zakresu tej problematyki, którą mi podsunąl mój Mistrz - autor wielkiego dzieła: "Zawarcie małżeństwa w pierwotnem prawie polskiem".

Jeżeli idzie o wyznaczenie prawnego punktu wyjściowego: do naszych balań nad wpływem bojaźni na zawarcie małżeństwa rzymskiego, to jest nim pojawienie się w I w. p.n.e,

1 Prócz obowiązikowegio seminarium dla stưlentów prowadzil Prof. Abraham jeszcze seminarium nieoloowiązkowe dla asystentów, docentów i profesorów, na którym omawiano nieopracowane jeszcze zagadnienia z zakresu kościelnego prawa $\mathrm{w}$ Polsce. 
edyktu pretorskiego Quod vi metusve (w późniejszej redakcji Quod metus) causa gestum erit, ratum non habebo. Jak wiadomo, w tym ogólnym edykcie pretor zapowiedział, że nie będzie uznawał aktów prawnych pochodzących $\mathrm{z}$ groźby względnie bojaźni i że w takim przypadku udzieli poszkodowanemu skargi na rozerwanie względnie unieważnienie danego aktu prawnego.

Nie będziemy tu wchodzilj w szczegółowe rozpatrywanie pytania, czy j. o ile edykt ten jest oryginalną myślą rzymską. W każdym bądź razie w nauce utrzymuje się przeświadczenie, że co się tyczy głównych elementów tego edyktu, sięgają one swymi korzeniami Arystotelesowskiej Etyki nikomachejskiej. ${ }^{2}$ Pomijamy zawarte $\mathrm{w}$ niej wstępne założenia, jak np.: „,rozgraniczenie rzeczy zależnych od woli, i rzeczy od niej niezależnych, jest chyba czymś koniecznym dla tych, którzy zastanawiają się nad dzielnością etyczną, pożyteczną zaś także dla prawodawców przy przyznawaniu zaszczytów i wymierzaniu kar. Otóż za niezależne od woli uchodzą te rzeczy, których się dokonywa bądź pod przymusem, bądź skutkiem nieświadomości. Przymusowe zaś jest to, czego przyczyna tkwi poza podmiotem $i$ jest tego rodzaju, że ten, kto jest podmiotem lub przedmiotem odnośnego działania, wcale się do niego nie przyczynia ... Co się zaś tyczy czynów, których się dokonuje $z$ obawy przed większym złem ... to jest rzeczą wątpli-

- Zob.: Maschke, Die Willenslehre im griechischen Recht, (1926), S. 137-149; von Lübtow, Der Ediktstitel „Quod metus causa gestum erit", Greifswald 1932, 61-79, 111; Schu1 $\mathrm{z}$ F., Die Lehre vom erzwungenen Rechtgeschäft im antiken rómischen Recht, Zeitschrift der Savigny - Stiftung für Rechtsigeschichte (= ZS) 43. Rom. Abt. s. 18-182; K $\mathrm{u}$ ble r, Griechische Einflüsse auf dive Entwicklung der römischen Rechtswissenschaft gegen Ende der republikanischen Zeit, Atti del Congresso Internazionale di Diritto Romano (1933), Vol. I, s. 94 n.; Coing, Zum Einfluss der Philosophie des Aristoteles auf die Entwicklung des römischen Rechts, ZS 69. s. 54-55; W y s z y ń k i M., Quamvis si liberum esset noluissem, tamen coactus volui (D. 4, 2, 21, 5, Paulus), Zeszyty Nlaukowe Uniłwersytetu Wroclawsikiego Ser. A, $\mathrm{Nr} .15$ (1958), s. 164-167; Tenże De matrimonio romano ob metum contracto, Prace Wroclawskiegio Towarzystwa Naukowego, Ser. A. Nr 80. 
wą, czy taki czyn jest od woli zależny, czy tė̇ niezależny ... Takie więc czyny mają charakter mieszanych, lecz zbliżają się bardziej do czynów od woli zależnych". Natomiast przytoczymy, co powiedział Arystoteles o męstwie jako środku w odniesieniu do bojaźliwości i odwagi: ,... boimy się zaś — oczywiście rzeczy strasznych, te zaś są - w bezwzględnym tego słowa znaczeniu - czymś złym; dlatego też strach określa się jako oczekiwanie czegoś złego. Otóż boimy się wszystkiego, co jest złe, np. niesławy, ubóstwa, choroby, osamotnienia, śmierci, zdaje się jednak, że męstwo dotyczy nie wszystkiego, co jest złe, sa bowiem rzéczy, których bać się jest nawet powinnością i czymś szlachetnym, nie bać się -- czymś haniebnym, tak np. niesławy... Nie należy natomiast może obawiać się ubóstwa, ani choroby, ani niczego $z$ tych rzeczy, które nie pochodzą $z$ nikczemności, ani $z$ własnej winy ... wobec których tedy rzeczy strasznych okazuje się człowiek mężnym? Chyba wolbec tych, co sa nimi w najwyższym stopniu, bo nikt nie jest bardziej zdolny do narażania się na to, co straszne (aniżeli człowiek mężny). Najstraszniejszą zaś rzeczą jest śmierć, gdyż jest kresem wszystkiego, a dla zmarłego nie ma już przypuszczalnie nic dobrego ani złeg.." 3

Mając przed oczyma powyższe powiedzenia, zestawmy z nimi odpowiednie zasady, do których $\mathrm{w}$ związku $\mathrm{z}$ pretorskim edyktem doszło prawo rzymskie. Oto one:

Z IV księgi Digestów II tytułu: Quod metus causa gestum erit:

L. 2 Paulus libro primo sententiarum. Vis autem est maioris rei impetus, qui repelli non potest.

L. 3 Ulpianus libro undecimo ad edictum. Sed vim accipimus atrocem et eam, quae adversus bonos mores fiat.

L. 4 Paulus libro undecimo ad edictum. Ego puto etiam servitutis timorem similiumque admittendum.

- Arystoteles, Etyka nikomachejska, przelożyła Daniela Gromska, Państwowe Wydlawnictwo Naukowe (1956), Ks. III Rozdz. I. s. 73 n., Rozkdz. VI S. 96 n. 
L. 5. Ulpianus libro undecimo ad edictum. Metum accipiendum Labeo dicit non quemlibet timorem, sed maioris malitatis. L. 7. Ulpianus libro undecimo ad edictum. $\S 1$ Proinde si quis in furto vel adulterio deprehensus, vel in alio flagitio, vel dedit, vel se obligavit. Pomponius libro vicesimo octavo recte scribit, posse eum ad hoc edictum pertinere, timuit enim vel mortem vel vincula.

L. 8 Paulus libro undecimo ad edictum ... et praetor non respicit, an adulter sit, qui dedit, sed hoc solum, quod hic accepit metu mortis illato. $\S 1$ Quodsi dederit, ne stuprum patiatur vir seu mulier, hoc edictum locum habet, cum viris bonis iste metus maior quam mortis esse debet.

L. 21 Paulus libro undecimo ad edictum. Si mulier contra patronum suum ingrata facta, sciens se ingratam, cum de suo statu periclitabatur, aliquid patrono dederit vel promiserit, ne in servitutem redigatur, cessat edictum, quia hunc sibi metum ipsa infert.

L. 22 Paulus libro primo sententiarum. Qui in carcerem quem detrusit, ut aliquid ei extorqueret, quidquid ob hanc causam factum est, nullius momenti est.

D. 4, 6, 3 Ulpianus libro duodecimo ad edictum. Metus autem causa abesse videtur, qui iusto timore mortis vel cruciatus corporis conterritus abest.

Cod. 2, 4, 13. Diocletianu's et Maximianus. Interpositas metus causa transoctiones ratas non haberi edicto perpetuo continetur. nec tamen quilibet metus ad rescindendum ea, quae consensu terminata sunt, sufficit, sed talem metum probari oportet, qui salutis periculum vel corporis cruciatum contineat. Cod. 2, 20, 4 Gordianus. Si per vim vel metum mortis aut cruciatus corporis venditio a vobis extorta est.

Cod. 2, 20, 7. Diocletianus et Maximianus. Si donationis vel transactionis, vel stipulationis vel cuiusdam alterius contractus obligationis confectum instrumentum metu mortis vel cruciatu corporis extortum, vel capitales minas pertimescendo adito praeside provinciae probare poteris, hoc ratum haberi secundum edicti formam non patietur. 
Porównywując treść owych fragmentów prawa $z$ ođ̉nośnymi wypowiedziami Arystotelesa, już na pierwszy rzut oka uderza nas różnica co do zakresu przykładów na większe zło =

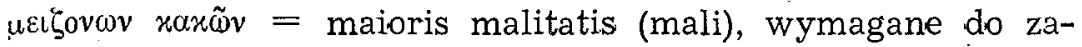
istnienia przymusu psychicznego. Gdy bowiem zakres $w$ Etyce nikomachejskiej został w przykładach zarysowany jakna'jszerzej, to nauka prawa rzymskiego ograniczyła go głównie do przypadków mortis, crutiatus corporis, servitutis, a dopiero na przełomie III i IV $\mathrm{w}$. n. e. poszerzyła go o vincula (carcer). Jeżeli w Paulusowym fragmencie D. 4, 2, 2 odlliczymy na rachunek interpolacyjny wyrażenie similiumque, otrzymamy $w$ wyniku tylko 4 przypadki zła, które słusznie Schliemann ${ }^{4}$ sprowadził do następującej wspólnej zasady: Gemeinsam ist die unmittelbare Beziehung des angedrohten Ubels auf die Person (nicht auf das Vermögen) des Bedroheten. $\mathrm{Na}$ taki właśnie rodzaj zła wskazuje naszym zdaniem również we fragmentach użyty kwalifikator - atrox.

$\mathrm{Z}$ kolei należałoby $\mathrm{w}$ tym miejscu przejść do rozpatrzenia przymusu psychicznego od strony bojaźni osoby zagrożonej. Nie tu miejsce na szersze badanie. To też, gdy idzie o bliższe określenie bojaźni względnie strachu, ograniczymy się do wyżej przytoczonej Arystotelesowskiej definicji: „strach określa się jako oczekiwanie czegoś złego". $5 \mathrm{Na}$ grunt rzymski przeniósł to określenie Cicero: „Si spes est expectatio boni, mali expectationem esse necesse est metum (Tusc. IV, 7); timorem metum mali adpropinquantis definiunt (ibid. IV, 19); definitio metus est diffidentia expectati et impendentis mali," (ibid. IV, 80). Rzecz znamienna, że $w$ tej formie nie przeszło ono do sfery prawnej, bo w pierwszym fragmencie D. 4, 2 spotykamy określenie takie: „metus instantis vel futuri periculi causa mentis trepidalio". Na pytanie, czy i jaką wartość wniosła owa mentis trepidatio, odpowiedzieliśmy już swego

4. Schliemann A., Die Lehre vom Zwange, Rastock 1861, 19.

5 Arystoteles, Etyka nikom. 96. 
czasu. ${ }^{6}$ Tu tylko przypomnimy, że jej genezy dopatrujemy się $w$ filozoficznej myśli greckiej, zwłaszcza stoickiej. Ponieważ doświadczenie wykazywało, że z chwilą zaistnienia jakiegoś fizycznego niebezpieczeństwa występowały pewne zmiany cielesne, ujęli stoicy owe doznania jako poruszenia xivnots

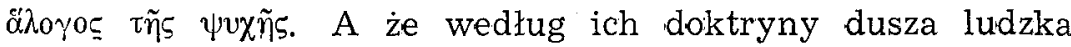
nie jest niczym innym jeno wysublimowaną materią, więc gdy przyszło określać doznania psychiczne bojaźni, ujęli je sensualistycznie, bo nazwali również poruszeniami.

Ale stoicy nie kładli na równi poruszeń zmysłowych (cielesnych) z psychicznymi. Pierwsze były według nich konnaturalne, od rozumu niezależne i w swoim natężeniu $z$ reguły proporcjonalne do wielkości groźby. Natomiast psychiczne sprzeciwiały się idealnej rozumnej naturze ludzkiej. Co do natężenia były one uzależnione nie tyle od obiektywnej groźby, ile od stanu rozumu człowieka. Twierdzili, że z reguly stan rozumu u ludzi jest osłabiony nabytymi namiętnościami i przez to staje się zmiennym, czyli ,nierozum-

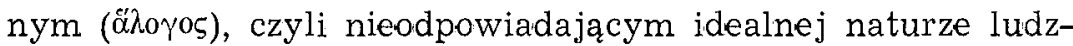
kiej. Temu właśnie psychicznemu zaburzeniu nadał Epikur

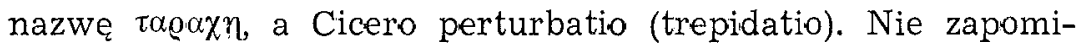
najmy, że gdy perypatetycy prócz rozumnej części duszy Iudzkiej wymieniali jeszcze jej część nierozumną i $z$ tą ostatnią wiązali uczuciowe zjawiska psychiczne, to stoicy zwłaszcza począwszy od Chryzypa -, widzieli we wszystkich czynnościach jedynie funkcję samego rozumu-oczywiście z reguły osłabionego. Wy'starczy w tym miejscu przytoczyć powiedzenie Cycerona: ,perturbationes autem nulla naturae vi commoventur, omniaque eae sunt opiniones ac iudicia levitatis (fin. III, 35); ut sunt alii ad allios morbos (corporis) procliviores, ...sic alii ad metum... vitiositas autem est habitus aut adfectio in tota vita inconstans et a se ipsa dissentiens... Ipse etiam metus non est morbi admodum similis, quamquam aegritudini est finitimus" (Tusc. IV.27,28,29,32).

6 Wyszyńki M., Metus maioris malitatis $w$ prawie rzymskim, Zeszyty Naukawe Uniwersytetu Wroclawskiego Ser. A (1956) $\mathrm{Nr}$ 6, s. $39 \mathrm{n}$. 
Oczywiście przy takim poglądzie na ludzi nierozumnie rozwiązujących swój stosunek do groźby, nie dziwimy się, dlaczego Cicero odniósł się do nich z pewną pogardą: „Quis non odit sordidos, vanos, leves, futtiles?" (fin.III,38), a Celsus wykluczył ich z korzystania z edyktu Quod m.c.: „Neque enim vani timoris ulla aestimatio est (D. 42, 1, 13); vani timoris iusta excusatio non est" (D. 50, 17, 184).

Alle wróćmy jeszcze do Cicerona. Nie poprzestał on na tym negatywnym typie człowieka bojącego się (vani, timidi, meticulosi hominis), bo przeciwstawił mu typ pozytywny w słowach: „Et si corporis est quaedam apta figura membrorum cum coloris quadam suavitate quae dicitur pulchritudo, sit in animo opinionum iudiciorumque aequabilitas et constantia cum firmitate quad'am et sta'bilitate virtutem subsequens aut virtuti vim ipsam continens - pulchritudo vocatur (Tusc. IV, 31); quod e't bonus vir fuit et multi Epikurei et fuerunt et hodie sunt et in amicitia fideles et in omni vita constantes... (fin. II, 81); quem hominem? mobilem? immo constanitissimum (Q. Rosc. 49); est aliquid quod perturbata mens melius possit facere quam constans?" (Tusc. IV. 54). Celowo na ten pozytywny typ, przez Cicerona przedstawiony, zwracamy uwage, bo chcemy wskazać, skąd go zaczerpnął Gaius, gdy przyszło mu wprowadzać do sfery prawnej człowieka, który nie tylko miał być przeciwieństwiem bojaźliwego, ale i miarą rozumnie odważnego: D. 4, 2, 6, Gaius libro quarto ad edictum provinciale. Metum non vani hominis, sed qui merito et in homine constantissimo cadat, ad hoc edictum pertinere dicimus. Rzecz charakterystyczna, że z trzech przez Cicerona użytych określników sapiens, vir bonu's, homo constantissimus wybrał właśnie ten ostatni.

\section{II}

Poznawszy $w$ skrócie podstawowe wyniki do zaczepiania poprzez pretorski edyk't Quod m. c. przymuszonych aktów prawnych, możemy teraz przejść do rozpatrzenia prawnej 
wartości przymuszonego małżeństwa i $\mathrm{z}$ tym zagardnieniem wiążącej się sprawy metus reverentialis.

Stwierdźmy z góry, że nie są to - jakby się na pierwszy rzu't oka wy'dawało - sprawy łatwe do rozwikłania.

Przede wszystkim należy sobie uświadomić, że w nauce zarysowało się $w$ ostatnich czasach rozdwojenie w odpowiedzi na zasadnicze pytanie, czy samo zawarcie małżenstwa rzymskiego należało już przed pojawieniem się edyktu Quod m.c. do sfery prawnej. Gdy bowiem jedni, idac za tradycyjnym poglądem, dają jeszcze dzisiaj na to pytanie odpowiedź pozytywną, to drudzy ${ }^{7}$ - do których i my się dolączamy ${ }^{8}$ - uważają zawarcie małżeństwa rzymskiego $\mathrm{w}$ tym czasie za akt metajurydyczny i osadzaja je na zastarzałych postulatach rzymskiej etyki społecznej. Oczywiście, w tym drugim poglądzie konsens małżeński nie może mieć znaczenia voluntatis initialis contractus, nakładającej na obie strony prawne zobowiązanie, lecz tylko specyficznego porozumienia (voluntatis continuativae), skierowanego na nawiązanie wspólnego życia w charakterze męża i żony, porozumienia, które mogło być rozerwane prywatnie już to przez samych małżonków już to przez ich ojców. Otóz $w$ mastępstwie owego rozdwojenia $w$ nauce inna musi być odpowiedź $\mathrm{w}$ sprawie przymuszonego konsensu małżeńskiego, wziętego $\mathrm{w}$ znaczeniu prawnym, a inna rozpatrywanego od strony etyki społecznej. W pierwszym bowiem przypadku należy rozpatrywać zawarcie przymuszonego malżeństwa rzymskiego na równi $z$ innymi kontraktami konsensualnymi, w drugim zaś takie rozważanie staje się bezprzedmiotowym, ponieważ znajduje się poza zasięgiem edyktu Quod m. c. Ale na tym nie koniec. Między zaliczającymi zawarcie małżenstwa rzymskiego do sfery prawnej są i tacy, ktörzy ze względu na wspomnianą wyżej voluntas continuativa konsensu małżeńskiego nie stawiają na równi z innymi kontraktatami. Co więcej. Nawet wśród tych, którzy uznają

7 Kaser, Das römische Privatrecht I, München 1955, $\S 17$, s. 63 n. z Titeraturaz.

8 Wyszyński. M., De matrim. rom., $22 \mathrm{n}$. 
zawarcie małżeństwa za kontralkt konsensualny wskazać można itakich, którzy mimo wprowadzenia edyktu Quod m. c. zatrzymują nadal pierwotną nienaruszalność przymuszonego małżeństwa. A cóż dopiero mówić o takim poglądzie, że już W okresie klasycznego prawa rzymskiego iuris-prudencja była przeświadczona, i̇z $z$ punktu widzenia prawa naturalnego nie da się z przymusem pogodzić zawarcia małżeństwa.

1. Jakżeż przy takim zróżnicowaniu poglądów na przymuszone małżeństwo $\mathrm{w}$ czasie pojawienia się edyktu Quod metus causa urobic sobie zdanie o wpływie metus reverentialis na jego zawarcie?

Otóż oświadczamy, że gdybyśmy nawet stanęli na stanowisku tych, którzy zawarcie małżeństwa rzymskiego już w tym czasie zaliczają do sfery prawnej, to nie przyznalibyśmy metui reverentiali żadnego wpływu na zaistnienie tego aktu prawnego. A to $\mathrm{z}$ następującego powodu: Jak wykazar liśmy wyżej, do zaczepienia przymuszonych aktów prawnych domagała się nauka prawa rzymskiego od zainteresowanego z jednej strony, by groźba należała do najwyższej rangi cielesnego zła, z drugiej zaś, aby zagrożony zachował się wobec takiej groźby jako vir constantissimus. Jeżeli tedy nie obydwom tym wymogom, to $\mathrm{w}$ każdym bądź razie pierwszemu nie mógl $w$ tym czasie odpowiedzieć metus reverentialis, choćby i największy. Że w swej ka'tegorii także metus reverentialis mógł sięgać rangi najwyższej, wystarczy z Terencjuszowskiej komedii Phormio przyłoczyć oburzenie ojca na zachowanie się syna:

Itane tandem uxorem duxit Antipho iniussu meo?

Nec meum imperium - ac mitte imperium - non simultatem meam

Revereri saltem! Non pudere! O facinus audax...

Ale ojciec ten ze swoim oburzeniem na brak szacunku ze strony syna nie był podobny do ojca $z$ komedii Adelphoe tegoz samego autora: „Pudore et liberalitate liberos retinere satius 
esse credo quam metu" (57-58), bo sięgnął do przysługującej mu władzy i to małżeństwo potraktował jako niezawarte.

Zdaniem naszym myliłby się ten, ktoby twierdził, że owo w czasach Terencjuszowskich odwolywanie się patris familias do należnego mu szacunku ze strony dzieci zmalało $w$ następnych pokoleniach. Ale o tym niżej. Tu tylko przytoczymy retorską deklamację przypisywaną Kwintylianowi: „Nunc ille quod pietate, quod videor istius perire reverentia..." Czynimy to $z$ rozmysłu, bo za chwile przyjdzie nam rozprawiać się z powiedzeniem wielkiego prawnika Celsusa, w którym pewna grupa badaczy dopatrywała się zagadnienia metus reverentialis. To powiedzenie zostało nam przekazane przez Justyniańskich kompilatorów w następującym brzmieniu:

Celsus libro decimo quinto digestorum. Si patre cogente ducit uxorem, quam non duceret, si sui arbitrii esset, contraxit tamen matrimonium, quod inter invitos non contrahitur: maluisse hoc videtur (D. 23, 2,22).

Nie będziemy tu wchodzili w szczególowy rozbiór tego dla przymuszonego małżeństwa rzymskiego najważniejszego źródła prawnego. Nadmienimy tylko, że w przeświadczeniu ogółu badaczy teksit tego fragmentu zostal uznany za interpolowany, ale jak daleko sięgaja owe interpolacje i kto ich dokonał, zdania badaczy się rozchodzą. Np. Schulz ${ }^{9}$ i won Lübtow 10 twierdzą, że $\mathrm{w}$ oryginalnym tekście było tamen non contrahit i że owo non skreślili dopiero kompilatorzy Justyniańscy. Oczywiście, jeżeli się weźmie słowo cogente w znaczeniu ściśle prawniczym, to trudno dziwić się owym bada czom, że domagają się niezawarcia przymuszonego małżeństwa. Inni natomiast, jak np. Bonfante 11 i Beseler 12 biora slowo cogente $w$ znaczeniu szerszym, mianowicie dopatruja się $\mathrm{w}$ nim metus reverentialis i każą Celsusowi rozstrzygać

\footnotetext{
9 Schulz, Die Lehre. $192 \mathrm{n}$.

10 von L übtow, Der Ediktstitel. $23 \mathrm{n}$.

11 Bonfante, Corso $I, 198$.

12 B eseler, Miscellanea, ZS 44, 1924, 394; Tenże odwolal swój pogląd W Iuristische Wochenschrift 1932 III B. s. 3758.
} 
pytanie, czy nie należałoby $\mathrm{w}$ formie wyjątku takiemu właśnie przymusowi przyznać mocy hamującej zawarcie małżeństwa. Ale - ich zdaniem - Celsus nie zgodził się na taką koncepję i dlatego na to pytanie odpowiedział negatywnie, czyli innymi słowy odmówił $\mathrm{w}$ tym fragmencie metui reverentiali wpływu na niezawarcie małżeństwa. I w ten włáśnie sposób powstało $\mathrm{w}$ nauce $\mathrm{z}$ okazji wyjaśniania skomplikowanego fragmentu Celsusowego nasze zagadnienie.

A jednak mimo wszelkich pozorów prawdopodobieństwa ta koncepcja Bonfantego i Beselera nie przyjęła się. Pogląd Schulza i von Lübtowa o tyle był silniejszy, że opierał się na ścisłym rozumieniu słowa cogente, a więc na argumencie, który - o ile się nam wydaje - skłonił Beselera do odwołania postawionej przez niego tezy i do ograniczenia Celsusowego tekstu tylko do początkowego zdania głównego: Si patre cogente duxit uxorem, quam non duceret, si sui arbitrii esset, contrahit tamen matrimonium. Przy tym ten badacz zaznaczył, że dlattego ów ojcowski przymus małżeński uznał Celsus za nieskuteczny, bo wprawdzie mial przez prawo wymaganą rangę większego zła, ale był sprawiedliwy.

Co sądzić o tej ostatniej beselerowskiej koncepcji? Otóż przyjęlibyśmy ją $w$ całości, gdyby już $w$ czasie pojawienia się Celsusowego fragmentu małżeństwo rzymskie przeszło ze sfery etyki spolecznej do prawnej. Jednak na to nie mamy żadnego dowodu. Dlatego, gdy przychodzi nam w tym miejscu rozwiązywać Celsusowskie zagadnienie, jesteśmy zmuszieni odesłać czy'telnika do szczegółowej na ten temat napisanej naszej pracy. ${ }^{13}$. A doszliśmy $w$ niej do następującego wyniku: Lenel ${ }^{14}$ wykazał, że Celsus $\mathrm{w} \mathrm{XV}$ księdze swoich digestów nie zajmowal. się wcale prawem małżeńskim, ale spadkowym (D. 29, 2, 6, 7), i że właśnie tam przy okazji rozpatrywania zagadnienia obejmowania spadku przytoczył jako przykład zawarcia małżeństwa przez syna mimo wywartego na nim przymusu ojcowskiego (D. $23,2,22$ ). Jeżeli tedy te oba frag-

13 Wyszyński M., De matrim. rom., 7 .

14 Lene1, Paling. 1, s. 145 . 
menty Celsusowe w rekonstrukcji Beselerowskiej ${ }^{15}$ połączymy razem, otrzymamy wspólny tekst taki:

Celsus... (scribit) [scripsit] eum, qui (mihi bona fide servit, si iussu meo) [metu verborum (verberum? so Stephauns) ,vel aliquo timore coactus fallens] adierit hereditatem, sive liber sit, heredem non fieri [place't], sive servus sit, dominum heredem non facere. Si patre cogente ducit uxorem, quam non duceret, si sui arbitrii esset, contrahit tamen matrimonium.

Po takiej rekonstrukcji oryginalnego tekstu wspólnego uznaliśmy, że náleży treść Celsusową odczytać w sposób następujący: W przypadku, gdy bona fide serviens homo liber suam conditionem nesciens przystąpi na rozkaz względnie pod przymusem swego bona fide possessoris do objęcia spadku, nie może go robjąć dla siebie, ponieważ działając jako wykonawczy organ cudzej woli nie mógł on $z$ powodu niewiedzy - swoim obiektywnym stanie społecznym dokonać własnego oświadczenia woli w kierunku nabycia tegoż spadku. Inaczej natomiast ma się sprawa $z$ zawarciem małżeństwa przez syna działającego pod przymusem ojcowskim. W tej czynności syn nie jest podidanym woli ojcowskiej, to też zawiera małżenstwo dla siebie. Oczywiście byłby syn organem, gdyby zaszedł wypadek przymusu fizycznego, ale Celsus ma tu na myśli przymus psychiczny (vim compulsivam), co zaznaczyl bocznym zdaniem względnym quam (uxorem) non duceret, si liberi arbitrii esset, wyrażeniem, które później wejdzie w Paulusową formułę: Quamvis si liberum esset noluissem, tamen coactus volui D. 4, 2, 21, 5). Zatem, jak $z$ tego przedstawienia treści wynika, fragment Celsusowy Si patre cogente w powyższym kontekście odczytany musiał użyć słowa cogere w znaczeniu ściśle prawnym, a spełniając rolę kontrastu do nieobjęcia spadku, musiał mówić o zawarciu przymuszonego małżeństwa. Tych stwierdzeń naszych nie osłabia wcale fakt, że Celsus rozwiązując skomplikowane zagadnienie spadkowe sięgnął po kontrastowy przykład do zawarcia małżeństwa,

$15 \quad$ B eseler, Miscellanea s. 393. 
a więc do sfery metaiurydycznej. Wspólnym łącznikiem była wszakże tu i tam ta sama możność względnie niemożność dokonania mimo przymusu wystarczającego konsensu. W każdym bądź razie najważniejsze źródło prawne, w którym pewna grupa badaczy chciała powiązać zagadnienie wpływu metus revetentialis na zawarcie przymuszonego małżnstwa rzymskiego, okazało się zupełnie nieprzydatne.

2) Przejdźmy do czasów pocelsusowych.

Najpierw przypatrzmy sie, czy w tym okresie czasu nie dostało się ze sfery etycznej do prawnej jakieś zagadnienie powinnego szacunku dzieci dla rodziców. Według w tym przedmiocie dokonanych badań Kasera ${ }^{16}$ wchodziłyby $w$ rachubę następujące normy prawne: „Praeter: parentem, patronam in ius sine permissu meo ne quis vocet" (Ulpianus D. 2, pianus D. $2,4,4,1) ;$...permissurus enim est, si famosa actio non sit [vel pudorem non suggillat], qua patronus convenitur [vel parentes] (eod. Ulp. D. eod 1, 12); Sed nec famosae actiones adversus eos dantur, nec haec quidem quae doli vel fraudis habent mentionem (Ulp. D. 37, 15, 5, 1) i inne. Przytoczyliśmy te zakazy prawne dlatego, aby dać dowód, jak wysoko byl ceniony szacunek dzieci dla ojca rodziny $w$ klasycznej dyscyplinie prawnej.

Ale chyba byłoby rzeczą zbyteczną podkreślać, że poza powyższą prawnicza miarą wartości szacunku była nie mniejsza

${ }_{16} \mathrm{~K}$ ase $\mathrm{r}$, Der Inhalt der patria potestas, ZS. 58, (1938), $62 \mathrm{n}$; Tenże, Die Geschichte der Patronatsgewalt über Freigelassene, tamże $88 \mathrm{n}$. W sprawie reverenitia s. 112-119 autor na stronie 118 zaznacza: Aber die Utberlieferung machit es zweifelhaift, ob dieses Wort bereits dem Schprachgebrauch der klassischen Iuristen angehört. Chodzi tu glównie o fragment D. 2, 4, 6. Paulus libiro primo sententiarum. Parentes naturales in uus vocare nemo potest: una esit enim omnibus parentibus servandia reverentia. Beseler, Beiträge zur Kritik der römischen Rechtsquellen, H. 1, Tübingen $1910,52,53,91$; s. 52: D. 36, 1, 52. Papinian... (sed paternae reverentiae congruum est egenti forte patri officio dudicis ex accessionibus hereditariis emolumenitum praestari); 91 D. 25, 2, 3. Paulus libno septimo ad Sabinum... (tamiten propter reverentiam personarum in utroque casu furtivam tantum conditionem campetere...). 
jego siła moralna. Podniosła ją niewspółmiernie wysoko chrześcijańska etyka i poszerzyła dla obojga rodziców, choćby przez czwarte przykazanie: „Czcij ojca i matkę swoją”, a zwłaszcza przez najwyższą sankcję, o której Ambroży ${ }^{17}$ tak pisał: „Offcia autem ab honesto et utili duci existimaverunt et de iis duobus eligere quod praestat deinde incidere, ut duo concurrant honesta et duo utilia et feratur, quid honestius et quid utilius... Nos autem nihil omnino nisi quod deceat et honestum sit, futurorum magis quam praesentium metimus formula nihilque utile, nisi quod ad vitae illius aeternae".

Zanim w świetle powyższej rangi szacunku dzieci dla rodziców przejdziemy do rozpatrzenia wplywu $w$ tym czasie metus reverentialis na zawarcie przymuszonego małżeństwa, zdajmy sobie jeszcze przedtem sprawę ze zmiany jaka zaszła w pocelsusowym okresie we władzy ojcowskiej. Pomijamy fakt, że W IV w. stracil pater familias nad dziećmi władzę vitae necisque. Jeszcze wcześniej odebrano mu starodawną. władzę do przymuszenia dzieci do zawierania małżeństwa. Oto odnośne zakazy:

Terentius Clemens libro tertio ad legem Iuliam et $\mathrm{Pa}$ piam. Non cogitur filius familias uxorem ducere. (D. 23, 2, 21). Impp. Diocletianus et Maximianus AA. Sabino. $\mathrm{Ne}$ filium quidem familias invitum ad ducendam uxorem cogi legum disciplina permittit. Igitur, sicut desideras, observatis iuris praeceptis sociare coniugio tuo quam volueris non impediris, ita tamen, ut in contrahendis nuptiis patris tui consensus accedat. [a. 283] (C. 5, 4, 12).

Idem AA. et CC Titio. Neque ab initio matriomonium. contrahere neque dissociatum reconciliare quisquann cogi potest. Unde intelligis liberam facultatem contra-

17 Ambrosius, De officiis clericorum, Gilbert, Lipsiae 1839 , Lib. cap. IX, s. 27. Zoib. Gau demeit I., Parentes et infantes dans la doctrine patristique et la legislation comciliaire du Bas-Empire, Librairerie du Recueil Sirey 1959. 
hendi atqui distrahendi matrimonii transferri ad necessitatem non oportere. (C. 5, 4, 14).

Nie trudno chyba dopatrzyć się, jaki był cel tych zakazów. Wyszły one ze społecznej troski o trwałość pożycia małżeńskiego. ${ }^{18}$ Widocznie sięganie patris familias do przymusu małżeńskiego było częste i sprowadzało niepożądane skutki, jeżeli się zdecydowano na zrobienie we władzy ojcowskiej aż tak wielkiego wylomu. Tym bardziej zadziwia to historycznoprawne zjawisko, gdy się jeszcze zważy, że władza ojcowska była ograniczona niektórymi zakazami małżeńskimi Augusta, wywodzącymi się z etyki społecznej, wedle której syn mógł odmówić posłuszeństwa ojcu, ,si imperet uxorem ducere infamem, propudiosam, criminosam". Przy takim stanie rzeczy, gdy syn nie chciał na. rozkaz ojca zawrzeć danego związku małżeńskiego, co talkiemu ojcu pozostawało? Chyba tylko odwołać się do należnego mu szacunku - czyli reverentia i z tym szacunkiem łączącymi się uczuciami, jak verecudia, pietas, pudor. Gidy i to nie pomagało, nie pozostawało mu już nic innego, jak sięgać do gróźb mniejszych, np. wydziedziczenia itp. W ten oto sposób, jeżeli się nie mylimy, groźba względnie metus (timor) reverentialis — aby $w$ danym przypadku małżeńskim nie wejść $w$ kolizję $z$ należnym ojcu szacunkiem - urość mogły do znaczenia poważnego czynnika, ograniczającego od strony psychicznej wolę syna względnie córki, zawierających dany związek małżeński.

Lecz mimo naszego podkreślenia dokønanego $\mathrm{w}$ tym czasie awansu metus reverentialis nie mamy wcale zamiaru twierdzić, że jego wpływ na samo zawarcie małżeństwa stał się tym samym wielkim. Chyba, żebyśmy wzięli ten wpływ $w$ znaczeniu negatywnym. A to zdaniem naszym $z$ tego powodu, że tę samą rolę destruktywną dla pożycia małżeńskiego, którą dotąd pełnił prawny przymus ojcowski, przejął teraz

18 K aser, Das römische Privatrecht I \& 79. Biondo, Il diritto romano Christiano, Milano 1954, IIII n. 333. In s adowski H., Quid mamenti habuerit Christianismus ad ius romanum matrimoniale evolvendum. Acta Congressus iur. linternationalis (1935). Vol. II, $39 \mathrm{n}$. W yszyńs ki M., matrim. rom., $33 \mathrm{n}$. 
metus reverentialis sam lub wraz z lżejszymi groźbami. Co się zaś tyczy ewentualnego wplywu na sam konsens małżeński nie może być w naszym przeświadczeniu aż do piątego wieku mowy $z$ tej prostej przyczyny, ponieważ zwolennicy poglądu, zaliczającego samo zawarcie małżeństwa rzymskiego do sfery metajurydycznej dopiero z tym wiekiem łączą przeniesienie tej czynności do sfery prawnej.

3. Zbyt wielkim zdarzeniem historyczno-prawnym jest uznanie zawarcia małżeństwa za akt prawny $w$ tym czasie, aby je było można przy rozpatrywaniu naszego zagadnienia ograniczyć tylko do wskazania samego wieku. Idąc w ślad za podanymi przez Levy'ego ${ }^{19}$ źródłami: CT. 3, 7, (428); NAnth. 1 lin. 25, 35 (468); Cj. 5, 9, 6, 9 (472), przytoczmy teksty dwóch pierwszych:

Impp. Theod. et Valent. AA. Hierio PFP. Si donationum ante nuptias, vel dotis instrumenta, defuerint, pompa etiam, aliaque nuptiarum celebritas omittan'tur, nullus aestimet ob id deesse, recte alias inito matrimonio, firmitatem, vel ex eo natis liberis iura posse legitimorum aufferri, si inter pares honestate personas, nulla lege impediente, fiat consortium, quod ipsorum consensu atque amicorum fide, firmatur.

Legum novellarum divi Anthemii $1, \ldots$ inter quos huiusmodi est contractus societas... contractu vilissimae societatis..."

Jeżeli więc z pierwszego źródła dowiadujemy się, że do zawarcia małżeństwa wystarczy tylko konsens nowożeńców, dokonany $\mathrm{w}$ obecności przyjaciól, to $\mathrm{z}$ drugiego najwyraźniej wynika, że na podistawie tego konsensu zawarte małżenstwo ma już charakiter kontraktu spółki. Ale stwierdzając ten fakt ostatni, tym samym nie mamy zamiaru głosić, że był to kontrakt wzięty $\mathrm{w}$ ścisłym tego słowa znaczeniu. Już swego czasu Pernice ${ }^{20}$ dopatrywał się owej różnicy w niezaskarżalności za-

19. Levy E., Weströmisches Vulgarrecht, Das Obligationsrecht, Weimar 1956, 22.

20 Pernice, Parerga, ZS 9. (1888), s. 210. 
wartego małżeństwa rzymskiego, wywodzącej się zdaniem jego z zasady, że związek ten oparty na voluntas continuativa powinien być zawsze wolny od państwowego przymu'su. Nie umniejszając tego spostrzeżenia, skierowal Levy ${ }^{21}$ swoją uwagę na pewną inflację tego pojęcia contractus, twierdząc, że: Besonders vom fünften Jahrhundert ab fand das Wort unibedenklich Verwendung, wo im allgemeinsten Sinne eine bindende Uberreinkunft irgendwelcher Art ausgedrückt werden sollte." W każdym bądź razie, jeżeli idzie o wpływ w tym okresie czasu przymusu na zawarcie małżenstwa, to wydaje się nam, że już wtedy uważano takie związki małżeńskie za nieważne, a to głównie z przeświadczenia, że: „Nihil consensui tam contrarium est, qui ac bonae fidei iudicia sustinet, quam vis atque metus: quem comprobare contra bonos mores est. Ulpianus libro undecimo ad edictum (D. 50, 17, 116). Ale wykluczamy, aby $w$ zakres wspomnianej tu bojaźni wchodził $\mathrm{w}$ rachubę metus reverentialis.

Przechodząc do końcowego etapu naszych badań, tj. do Justyniana i jego kompilatorów, stajemy przed pytaniem, czy określony przed chwilą charakter prawny kontraktu małżeńskiego przẹszedł bez naruszenia do tego cesarza i został przez niego przyjety do sławnych zwodów prawa rzymskiego. Otóż Levy ${ }^{22}$ na to pytanie $\mathrm{z}$ miejsca odpowiedział: „Dem schloss sich Justynian nicht an. Seine Juristen fussten auf der klasschischen Auffassung, als für sie contractus nur eine Vereinbarung war, die Verpflichtungen begründete: so ausdrücklich Theophilus ad Insti. 3, 13, 2". Innymi słowy, akt zawarcia małżeństwa rzymskiego został przez Justyniana podciągnięty do rangi pełnoprawnego klasycznego kontraktu konsensualnego. Nie będziemy się tu wdawali w roztrząsanie; jakie powody skłoniły Justyniana do zrobienia właśnie takiego kroku. Powiemy tylko, że w następstwie tego pociągnięcia zniknęła $\mathrm{z}$ małżeńskiego kontraktu dotychczasowa voluntas continuativa, a jej miejsce zajęła volun'tas initialis.

21 Levy E., Westr. Vulg. Das Oblig. $s$.22.

22 Levy E., West-Östliches Vulgarrecht und Justinian, ZS (1959), 8. 
Ale poza tą zmianą, wypływającą ze zrównania przez Justyniana małżeństwa $z$ kontraktami $w$ rozumieniu prawa klasycznego, wymienić należy jeszcze nawrót do ujmowania wpływu groźby względnie bojaźni na przymuszone akty prawne. Jak już nadmieniliśmy, w zachodniej części państwa rzymskiego doszło w IV i V w. do przeświadczenia, że przy przymusie psychicznym nie mœżna mówić o zaistnieniu konsensu prawnego. Oczywiście $w$ następstwie takiego poglądu przestano mówić o zaczepialnonści danego aktu przymuszonego, a zaczęto go ujmować jako niedoszły do skutku, czyli nieważny. I od tego właśnie bądź co bądź szkodliwego przerostu kazal Justynian kompilatorom po dokonaniu pewnych zmian nawrócić do poglądu klasycznego, czyli do Paulusowej formuły coactus tamen volui i do ujmowania przymuszonych aktów prawnych jako zasadniczo zaistniałych, jakkolwiek po myśli Quod metus causa zaczepialnych. Powiedzieliśmy: zasadniczo, bo od tej zasady znało już klasyczne prawo wyjątki, w których dopatrywano się niezaistnienia danego aktu czyli jego nieważności.

I właśnie do liczby tych wyjątków musianю zaliczyć przymuszone małżeństwo $\mathrm{z}$ chwilą wciągnięcia go $\mathrm{w} \mathrm{V}$ w. do sfery prawnej. Tego domagal się specyficzny charakter małżeństwa, a więc zaciągnięte przez męża i żonę zobowiązania i uprawnienia, społeczne i państwowe funkcje. A to tym bardziej, że sprawa zaczepialności zaistniałego małżeństwa przy równoczesnej prywatnej moźności rozwiązania węzła małżeńskiego stałaby się $w$ Rzymie co najmniej dziwnym zjawiskiem prawnym.

Z rozmysłu zatrzymaliśmy się dłużej nad tym Justyniańskim podporządkowaniem również przymuszonego małżeństwa postulatom dawnego prawa klasycznego, bo chcemy w tym miejscu wykazać, w jak. kłopotliwym położeniu znaleźli się cesarscy kompilatorzy, gdy przyszło im w drugim tytule 23 księgi Digestów stwierdzić nieważność takiego małżeństwa. Zwracać się do cesarza o wydanie specjalnej konstytucji było niewskazane choćby $z$ tego powodu, że już $w V$ w., tj. od 
chwili wciągnięcia małżeństwa do sfery prawnej było ono uznawane $\mathrm{W}$ przypadku przymusu za nieistniejące, czyli nieważne. Sięgnąc do źródel dawniejszych nie mogli, bo takich nie było. Nie zostało im więc nic innego, jak tylko nawiązać do Celsusowego fragmentu Si patre cogente, fragmentu, który wprawdzie $w$ tematyce objęcia spadku spełniał rolę kontrastowego przykładu, ale za to $\mathrm{W}$ swojej własnej konstrukcji przypominał dokładnie Paulusową formułę coactus tamen volui. Zdawali oni sobie dobrze sprawę, że same mechaniczne oddzielenie tego fragmentu od jego sedis materiae nie rozwiąże sprawy i że przenюsząc go $z$ czasów Celsusowych do Justyniańskich trzeba będzie na nim dokonać poprzez interpelacje odpowiedniej adaptacji. $\mathrm{Na}$ czym ta adaptacja miała polegać, chyba nie trudno się domyślić. Wszak dla kompilatorów było jasne, że pater familias $w$ ich czasach już nie dysponował tą pełnowartościową możnością przymuszania syna do zawarcia małżeństwa, jaka mu przysługiwała za Celsusa, a jeżeli już sięgal do przymusu, to jego cogere nigdy nie moglo mieć znaczenia prawno-technicznego metus maioris malitatis, lecz tylko minoris-levis. Mówimy: nigdy, bo nawet w przypadku zawinionej przez syna bojaźni nie wolno było ojcu sięgać do groźby większej. To téz owo charakterystyczne przy przymusie psychicznym stanowisko przymuszonego, zaznaczone we fragmencie zdaniem: quam uxorem non duceret, si sui arbitrii esset, a przypominające Paulusowe quamvis si liberum esset, noluissem (D. 4, 2, 2, 5), jakkolwiek wzięte od strony psychologicznej, mogło się odnosić zarówno do przymusu ciężkiego jak i lekkiego, oczywiście w rozumieniu Arystotelesowskiej etyki i prawa rzymskiego miało zastosowanie głównie do metus maioris malitatis. Innymi słowy, gdy ktoś zawieral małżeństwo pod wpływem ojcowskiego przymusu lekkiego, mógł być z punktu widzenia prawnego uważany za takiego, kitóry i bez tego przymusu byłby tego aktu dokonał. Oczywiście, kompilatorzy chcąc dostosować ów fragment Celsusowy do potrzeb swoich czasów musieli to $\mathrm{w}$ jakiśs sposób zaznaczyć. I tu zdaniem naszym należy szukać początku owego krótkiego dodatku: maluisse hoc videtur. Po tej adaptacji 
włączenie do tekstu obowiązującej już od V w. zasady quod (matrimonium) inter invitos non contrahitur już nie przedstawiało właściwie żadnej trudności. Stwierdzenie tej zasady nie eliminowało wcale przy przymuszonym małżeństwie podstawowej formuly Paulusowej coactus tamen volui. Mieścila się ona przy przymuszonych aktach względnie kontraktach zaistniałych i zaczepialnych, jako że przy niezaistniałych, czyli nieważnych. Co się zaś tyczy użycia wyrazu invitus (inter invitos), przestanie ono intrygować, jeżeli się je postawi na tej samej płaszczyźnie, na której kompilatorzy umieścili maluisse videtur, a więc w połączeniu z Paulusowym Quam vis si liberum esset, noluissem.

Gdy tedy zbierzemy razem wszystko, co dotąd powiedzieliśmy o dokonanych nawrotach Justyniana $w$ sprawie przymuszonych kontraktów, a zwłaszcza o adaptacji Celsusowego fragmentu $\mathrm{Si}$ patre cogente $\mathrm{w}$ celu stwierdzenia nieważności przymuszonego małżeństwa ${ }^{23}$, musimy zaznaczyć, że nic nie zaszło takiego, co. wskazywałoby na poruszenie przez tego cesarza zagadnienia ewentualnego wplywu metus reverentialis na samo zawarcie małżeństwa. Wprawdzie posłużenie się kompilatorów fragmenitem Si patre cogente mogloby na pierwszy rzut oka nasunąc przypuszczenie, że chodziło im o rozpatrzenie owego zagadnienia - tego zdania byli Sanfilippo ${ }^{24} \mathrm{i} \mathrm{Sa}-$ chers ${ }^{25}$ - ale przy bliższym przypatrzeniu się przypuszczenie to musi odpaść jako bezzasadne. Okazuje się bowiem, że sięgnięcie kompilatorów do tego fragmentu stało się W pierwszej linii koniecznościa redakcyjną przy szukaniu źródeł prawnych na stwierdzenie nieważności przymuszonych małżeństw w ogóle, a dopiero w drugiej do przerobienia go na użytek czasów Justyniańskich. A to głównie z tej przyczyny, że bez tej adaptacji źródło to nie dałoby się żadną miara pogodzić z zaistniałą już od $\mathrm{V}$ w. zasadą o nieważności przymuszonego małżeństwa. A to wszystko tym bardziej, gdy się stwierdzi, że

${ }_{23}$ Wyszyński M., De matrim. rom, $48 \mathrm{n}$.

24 Sanfilippo C., Il metus nei negozi giuridici, Padowa 1934, s. $65 \mathrm{n}$.

25 Sachers, „Patria potestas” RE XXXI, $1046 \mathrm{n}$. 
w czasach Justyniańskich nie można znaleźć żadnego źródła prawniczego ani pozaprawniczego, które wskazywałoby na wyjątkowe podniesienie znaczenia metus reverentialis do rangi maioris malitatis. Przeciwnie, wydobycie ze źródeł specyficznego typu gróźb większych — jak to już wykazaliśmy w I części naszych dociekań - to dzieło nie czyje inne, tylko wyłącznie Justyniańskich kompilatorów. A typ ten jak najwyraźniej wyklucza tego rodzaju groźby, jak metus reverentialis.

\section{III}

1. Z kolei przechodzimy do 500-letniego okresu, który przegradza Zbiory Justyniańskie od początków szkól glossatorskich i to zarówno prawa rzymskiego jak i kanonicznego.

Co się tyczy prawa rzymskiego, to należy z miejsca stwierdzić, że przy zaistniałym jego w tym czasie wielkim kryzysie nie da się wiele powiedzieć o dalszych dziejach przymuszonego małżeństwa i $\mathrm{z}$ nim związanego zagadnienia metus reverentialis. Jeszcze na Wschodzie można sięgnąć do bazylik, wywodzących się ze Zbiorów Justyniańskich. Ale i one poza stwiedzeniem, że $1^{\circ}$ "quod metus causa gestum est, non valet" $(\mathrm{X}, 2,1) ; 2^{\circ}$, ,et metum maioris malitatis”; $3^{\circ}$,Et qui in virum

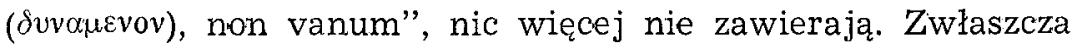
nie tylko że nie przytaczaja tekstu Celsusowego Si patre cogente, ale go nawet nie streszczają. A cóż dopiero mówić o wychowanym na źródłach 4 i 5 wieku Zachodzie, dla którego główny zbiór Justyniański - Digesty stał się zupełnie niedostępnym aż do 11 wieku.

Inna natomiast rola przypadla w tym czasie prawu kanonicznemu. Gdy bowiem na Wschodzie szło ono do czasów schizmy mniej lub więcej niezależnie od prawa cesarzy bizantyjskich, to po zerwaniu $\mathrm{z}$ kościołem katolickim związało się z prawem państwowym pod formą słynnego Nomocanonu. Natomiast na Zachodzie znalazł się kościół katolicki w innym położeniu. Mając przed sobą stare i nowe ludy, które na gru- 
zach państwa rzymskiego zaczęły sobie układać własne życie, mógł teraz $\mathrm{w}$ oparciu o dawniejsze swoje ośrodki życia religijnego przystąpić do dalszej pracy misyjnej i organizacyjnej, nie mówiąc o kulturalnej. Oczywiście, że wśród trudnnści, które napotkał $\mathrm{w}$ tej pracy ze strony miejscowych czynników, sprawy małżeńskie, jak sposób zawarcia i trwałość, musiały należeć chyba do najcięższych. Na dowód zaś, że i sprawa przymuszonych małzeństw nie była rozwiązywana jeszcze wtedy po myśli wymogów kanonicznych, wystarczy przytoczyć następujące dwa źródła.

Nicolaus Papa. Ubi non est consensus utriusque non est coniugium. Ergo qui pueris dant puellas in cunabulis et e converso faciunt, nisi uterque puerorum postquam venerit ad tempus discretionis consentiant, etiamsi pater et mater fecerint et voluerint. (C. XXX q. II, c. un.).

Iudicium Urbani Papae. Si verum esse constiterit quod nobis legati Iordanis principes retulerunt, scilicet quod ipse coactus et dolens filiam suam infantulam nolentem et flentem et pro viribus renitentem non assentientibus sed valde dolentibus matre et parentela, Rainaldo Rodeli, filio desponsaverit: quoniam canonum et legum auctoritas talia sponsalia... non aprobat: ...non prohibemus qui alli viro (si voluerit) praedicta filia eius nubat, tantum in Domino (C. XXXI q. II, c 1.). Nie ulega chyba żadnej wątpliwości, że obydwa przekazy źródłowe mówią o nieważności przez rodziców przymuszonych małżeństw. Również śmiało założyć można; że w obydwóch przypadkach działał metus reverentialis. Ale, czy on tylko jedyny? Twierdzimy, że na to pytanie należy odpowiedzieć przecząco, a to $\mathrm{z}$ następujących powodów: powolanie się Papieża Urbana na canonum et legum auctoritas wskazuje niedwuznacznie na od dawna już ustalone kościelnorzymskie stanowisko prawne $w$ tej sprawie. Pomijamy tu fakt, że stanowisko to zostało według naszych dociekań zajęte $\mathrm{w}$ V w. Natomiast przypominamy, iż nie ma żadnego źródła, które wskazywałoby, że przez prawo rzymskie określona większość i charakter groźby, powodującej nieważność 
przymuszonego małżeństwa, zostały na 500-letniej przestrzeni czasu zamienione przez prawo kanoniczne.

2. Mając tak zarysowaną postawę wyjściową do dalszych badań nad naszym zagadnieniem $\mathrm{w}$ okresie średniowiecznym, zaglądnijmy najpierw do zbiorów prawa kanonicznego, objętych techniczną nazwą Corpus iuris canonici, a zwłaszcza do Dekretu Gracjana i Dekretaliów Grzegorza IX.

Otóż okazuje się, że Gracjan w swoim Dekrecie utworzył osobną sedes materiae dla rozpatrzenia nieważności przymuszonych małżeństw, mianowicie C. XXXI q. II. c. 1. Oczywiście przy'toczone w niej źródła mają charakter wyłącznie kościelny. Zaczynają się od komentarza Ambrożego do Listu św. Pawła do Koryntian a kończą na rozstrzygnięciach Urbana II. Wszystkie domagają się od nowożeńców konsensu małżeńskiego, a niektóre $z$ nich wyraźnie podkreślają, aby ten konsens był wolny od przymusu: ,...nisi libera voluntate nulla est copulanda alicui..." $\mathrm{Na}$ uzasadnienie wymogu wolności od przymusu zostały $w$ tych źródłach wysunięte takie argumenty: ,nubat vidua cui vult, tantum in Domino: id est quem sibi aptum putaverit, illi nubat: quia invitae nuptiae solent malos proventus habere"... „quorum enim unum corpus est, unus debet esse et animus: ne forte virgo cum fuerit alicui invita copulata contra Domini Apostolique praeceptum: aut reatum dissidii, aut crimen fornicationis incurrat: cuius videlicet peccati malum in eum redundare constat, qui eam coniunxit in vitam, quod pari tenore de viro etiam est sentiendum". Co dotyczy charakteru i wielkości zastosowanej w poruszonych przypadkach groźby, źródła albo milcza, albo mówią o śmierci. Jak $z$ tego przeglądu podstawowych elementów przymusu małżeństkiego widać, to $\mathrm{w}$ zasadzie pokrywają się one $z$ wymogami prawa rzymskiego, jakkolwiek na jego źródła się nie powołują. W każdym bądź razie należy w tym miejscu stwierdzić, że dla naszego zagadnienia metus reverentialis poza przytoczeniem przypadków ojcowskiego przymusu Dekret Gracjana niczego więcej nie zawiera.

Gdy idzie o Dekretalia Grzegorza IX, to najpierw w tytule De iis quae vi metusve causa fiunt (I, 40) wyliczyły następu- 
jące ogólne zasady: "quare vi metusve causa fiunt carere debent robore firmitatis"; "quae metu et vi fiunt, de iure debent in irritum revocari"; violentia... cum neque metum mortis neque crutiatum corporis continere, et ideo non debuerat cadere in constantes viros". Jak z tego przeglądu widać, to pierwsze trzy zasady zostały wzięte bez wymienienia źródeł z prawa rzymskiego - czyli kanonizowane. Chyba nie musimy podkreślać, że to, co w Dekrecie Gracjana w stosunku do prawa rzymskiego zostało tylko zarysowane, wystąpiło w Dekretaliach Grzegorza IX już w postaci dosłownej. Zjawisko to daje się objaśnić chyba tylko tym, że z pojawieniem się Digestów na Zachodzie proces wciągania ich, względnie powoływania się na nie przez prawo kanoniczne dokonywał się powoli. Ale wróćmy do tematu. Przeglądając wszystkie źródła w obu tytułach (I, 40 i IV, 1) Dekretaliów Grzegorza IX stwierdziliśmy, że mimo zawartych $\mathrm{w}$ nich przypadków przymusu ojcowskiego nie natknęliśmy się na żaden choćby ślad, w którym byłoby poruszone zagadnienie metus reverentialis.

3. Po zestawieniu podstawowych dla naszego zagadnienia źródeł prawnych, zawartych $\mathrm{w}$ Corpus iuris civilis i $\mathrm{w}$ Corpus iuris canonici, przejdźmy z porządku rzeczy do rozpatrzenia rozbudowanej nad tymi źródłami nauki glossatorskiej. Mając na oku szczupłe ramy tego artykułu, nie będziemy się tutaj wdawali $\mathrm{w}$ śledzenie wyników poszczególnych glossatorów $\mathrm{w}$ naszej sprawie, ale odwołamy się do poglądów reprezentowanych przez trzy glossy, a mianowicie przez glossam ordinariam prawa rzymskiego, gl. do Dekretu Gracjana i gl. do Dekretaliów Grzegorza IX.

a) Zacznijmy od glossy Corpus iuris civilis. Otóż w zakresie podstawowych elementów, wymaganych przy stosowaniu edyktu Quod metus causa, wysunięto na pierwsze miejsce formułę Paulusową coactus tamen volui: „et sic nota, quod coacta voluntas, voluntas est. Unde versus. Sicque volens factus quod nollem velle coactus"' (ad D. 4, 2, 21). Innymi słowy wyjaśnianю, że według tej formuły działający pod przymusem wybiera ostatecznie to, czego nie chcial czynić. Na- 
stępny element - to wielkość groźby. Glossa zachowała w zasadzie pogląd wyrażony w źródłach. Uściśniła go tylko w dwóch punktach: że maioris malitatis oznacza magni (ad c. 5) i że przy wyłączonej infamii należy rozróżnić ,scilicet de facto... secus 'si infamia est, quae habeat iuris effectum (ad c. 7).

Przejdźmy do przymuszonego małżeństwa, czyli do glossy Akkursiusa ad „Si patre” (D. 23, 2, 22). Oto ona: „Sui arbitrii esset. cogitur a patre filius ut consentiat: sicque erit matrimonium: ut j. de tutel. 1. $21 \S$ idem Cassius"; ad „Invitos". Hic volens autem fuit, alias non valeret, ut hic. et $C$. 1 . nec. filium"; ad "maluisse" hoc quam odium patris incurrere. non autem dicas metum adhibitum, ut supra q. m. c. 1. si mulier $\S$ si dos". Z rozmysłu przytoczyliśmy dosłownie wypowiedzi glossy Akkursiusa, bo - jak widzimy - poruszone w niej zostało nasze glówne zagadnienie. Przede wszystkim stanęła glossa na stanowisku, że użyty we fragmencie Celsusowym wyraz cogente powinien być wzięty $w$ analogicznym znaczeniu do D. 26, 1, 3, 2: ,idem Cassius ait si pupillus curatorem poscere non vult, quo-minus cum eo agatur, cogi eum a praetore debuisse", czyli nie sensu stricto, ale lato. Następnie zawierający $w$ tym fragmencie małżeństwo filius został skwallifikowany, jako volens, a nie jako invitus. Wreszcie - dla naszego zagadnienia rzecz najważniejsza - glossa dopatrzyła się $\mathrm{w}$ tym przypadku metus reverentialis, ale nie bojaźni, należącej do kręgu groźb większych. Wprowadzenie przez Akkursiusa do nauki rzymskiego prawa małżeńskiego tej bojaźni musimy skwalifikwać jako historyczno-prawną nowość.

b) Co mówi glossa do Dekretu Gracjana?

W sprawie podstawowych elementów przymusu wystarczy przytoczyć następujące glossy: C. XV q. 1, c. 2 ad "Vult": ,Arg. quod coacta volunitas, est voluntas, ut hic, et XXIII $q$. III displicet. et $q$ VI vides. et LXXIV dist. consuluit et ff. quod met. cau. si mulier § ulti."; C. XV q. 6, c. I ad „Per metum". ,...Dum-modo talis sit metus, qui cadat in constantem virum: ut extra quod metu. causa $(=$ de his quae vi 
metusve fiunt) ad audientiam. Si quaeris qualis metus debeat cadere in constantem virum: dico quod qui continet metum mortis vel crutiatus corporis: ut extra eo. tit. cum dilectus. Coactio autem verborum non sufficit, etiamsi Rex sit, qui minetur. ut extra qui cler. vel voven. insignante. C. de transact. interpositas". W odniesieniu zaś do przymuszonego małżeństwa: C. XX q. IV, inter caetera ad "Matrimonium". "Videtur ex loco isto, quod coactio conditionalis non impediat matrimonium, sicut non impedit alia sacramenta ...Sed contra, matrimonia debent esse libera, et ibi animus debet gaudere plena libertate, ut extra de spons. requisitus, et cap. cum locum".; C. XX q. III, c. 4 ad „Patrem”. ,... Item habes hic, quod timor patris impedit matrimonium spirituale, licet secus videtur in matrimonio carnali, ut ff. de ritu nup. si patre cogente. Sed intellige de levi coactione". ${ }^{26}$

Jak $z$ powyższych wypowiedzi wynika, glossa przeniosła z Dekretaliów Grzegorza IX podstawowe elementy przymusu, pokrywające się $w$ zasadzie z elementami - jak wykazaliśmy wyżej - prawa rzymskiego. Również z tych samych Dekretaliów przytoczyła ona źródła na uzasadnienie, że zawarcie małżeństwa musi być wolne od przymusu. Ale najważniejsza rzecz, którą nam przyniosła owa glossa, a która dotyczy naszego zagadnienia, to sposób tłumaczenia fragmentu Celsusowego Si patre cogente. Mianowicie, gdy przyszło autorowi tej glossy stwierdzić, że Lambertus wstąpił do klasztoru pod ciężkim przymusem ojcowskim, przypomniał mu się prawem kontrastu rozstrzygnięty przez fragment Si patre cogente przypadek zawarcia małżeństwa także pod przymusem ojca. Oczywiście, gdyby $\mathrm{w}$ tym ostatnim przypadku zastosowany timor patris pochodził z groźby większej, musiałoby małżeństwo to na równi $z$ przymuszonym wstąpieniem Lamberta do klasztoru być uznane za niezawarte. Ale ponieważ fragmenit Celsusowy mówi wyraźnie o zawarciu małżeństwa, więc autor glossy

26 Por. glossę do „Matrimonium” C. XXXII q. 4. c. inter caetera: "Vel loquitur quando levis fuit coactio, idla enim non impedit matrimonium ff. rit. nup. Si patre cogente." 
doszedł do słusznego - zdaniem naszym - przeświadczenia, że ten przymus ojcowski należy zaliczyć do zakresu metus levis. I oto mamy drugą interpretację rzymskiego źródła $\mathrm{Si}$ patre cogente. Ujmujemy ją jako drugą, bo poznaliśmy juz wyżej Akkursiańską. Między nimi zachodzi ta różnica, że gdy Akkursiańska ogranicza ten przymus tylko do samego metus reverentialis, to glossa ordinaria do Dekretu Gracjana obejmuje wszysitkie przymusy lekkie nie wyłączając oczywiście propter odium patris. Stwierdzając w tym miejscu ową nowość, nie możemy nie zauważyć, ïz te obie interpretacje powstały w tych samych niemal czasach, z tym że „Gracjańska" wyprzedziła Akkursiańską.

c) Co dotyczy Dekretaliów Grzegorza IX, to jak wiadomo podstawowe elementy przymusu mieszczą się zasadniczo w I,40. Omówiła je przede wszystkim glossa do c. 2 ad "Coactus". w nasitępujący sposób: „Nota quod si quis per iustum amissionis rerum suarum aliquid faciat vel iurat se facturum et illud adimplet iuramentum, potest expetere quod tali modo fecit vel abiuravit. arg. I dist. presbyteros. Et intellige de talibus rebus sine quibus vita corporis amittitur, vel patitur gravem iacturam. XXII c. Innocens... Nota ergo ideo, quia coacta voluntas, est voluntas. XV q. I. merito quaeritur. Sed contra hoc datur actio quod metus causa, et probato metu restituitur per officium iudicis ei quod dedit vel tradidit: aut absolvetur si promisit. ff. eo. 1. metum $\S$ sed quod praetor... Tenent ergo quae per metum fiunt et subvenitur metum passis, nisi culpa sua incidant in metum. $\mathrm{Ab}$ ista doctrina sive generalitate excipiuntur casus in quibus fallit etiam si culpa sua incidisset in metum. Et primo in causa matrimonii qualisque metus interveniat culpa sua vel sine causa: matrimonium contractum per metum non tenet, nec obligatur qui hoc facit, etiam si iurat, quia matrimonia libera debent esse: quia invitae nuptiae difficiles exitus consueverunt habere. $: \mathrm{j}$ :. de spons. requisivit. et c. Gemma. et $\mathrm{C}$. de spons. l. ult. in fi. ubi metus vel coactio intercedit, consensus liber dici non potest. :j: de spons. cum locum. et matrimonium solo consensu contrahitur. XXVII q. II. sufficiat ... (Po przytocze- 
niu wyjątkowych przypadków, w których akty przymuszone nie dochodzą do skutku) ... In omnibus aliis casibus tenent quae per metum fiunt: ut dictum est: dum tamen talia sint, quae sine interitu salutis aeternae servari possint. alii dicunt contra, quod ea quae per metum fiunt non tenent ipso iure. argumentum. ff. eodem 1. I. ubi dicitur, quod metu factum est, ratum non habebo, dicit praetor. Sed illud non est verum, imo potius contra invenitur ex verbis illis: quia quod non est, ratum haberi non potest. Bernardus". $Z$ rozmysłu przytoczyliśmy prawie że w całości tekst tej glossy zasadniczej, bo chcemy wskazać, jak z prawa rzymskiego do kanonicznego został przeniesiony sposób stosowania pretorskiego edyktu Quod metus causa. Na razie zauważmy, jak glossa podzieliła skuteczność przymuszonych aktów, a więc na $\mathrm{W}$ zasadzie dokonane, ale przez poszkodowanych zaczepialne, i na ipso iure nie zaistniałe, czyli t. zw. „nieważne”. Pierwsza grupa stanowi regułę, druga zaś wyjątki. Do tych wyjątków należy przymuszone małżeństwo, a to $\mathrm{z}$ powodu swojego specyficznego ,uczulenia” na przymus, sięgającego zdaniem autora tej glossy aż do niezważania, czy przymus jest niesprawiledliwy, czy téz sprawiedliwy (zob. c. $15 \times 4,1$ ), oraz z przyczyny na szczególny charakter tej instytucji.

W odniesieniu do przypadków wystarczającej groźby mówi glossa przy c. 6 X I 4 ad „Metum mortis etc.": „Non solum in duobus istis (cum necque metum mortis, neque crutiatum corporis contineret), sed etiam in pluribus allis casibus excusat metus. quandoque metus verborum, arg. VII. dist. fuerunt. et XXIII q. VIII. convenior. et ff. de acqui. haere. qui in aliena. $\S$ ult. quandoque metus rerum. L di. presbyteros. et supra. c. abbas. et propter metum libertatis exigere non possum, qua onerandae libertatis causa stipulatus sum. ff. quarum rerum a'ctio non datur. L. I $\S$ quae onerandae, quandoque metus iudicis. II. q. I in primis, vel alicuius potentis C. eo. tit. 1. pe. et VI. quandoque metus status, vel honoris, vel suiipsius, vel filiorum, et metu stupri. ff. eo. isti quidem. Item quandoque non tantum metus, sed suspicio metus excusat. ff. loca. habitatores. $\S$ ult. et ff. ad l. Aquilatem si 
quis fumo $\S$ ulti. Quandoque metus mortis aut cruciatus corporis tantum excusare videtur, ut hic. et C. de transac. interpositas. Unde videtur reliquendum arbitrio iudicis, an verba vel minae vel potentia hominis sit iusta causa metus: ut ff. ex qui. cau. ma. l. III. et arg. ff. eo non est verisimile. Item subvenitur metum passo per hoc edictum quod metus causa, tunc tantum quando metus cadit in constantem virum. ff. eo. metus et $j$ :. de spons. veniens. Sed uibi quis minorem metum passus est, videlicet per impressionem sive potentiam iudicis officio, vel dolo alterius quis vendit suas res: tunc subvenitur ei iudicis officio. ff. eo. non est verisimile. $\S$ fi. vel per constitutionem principum $C$. eo. l. penul. et ulti. et ff. de off. praes. illicitas vel per responsa de var, et extraor. cog. medicus, iudex vero alicui non dicitur inferre metum ff. eo. 'l. III. sed iniuriam facere potest, ut ibi. ff. ad 1. Aquil. quemadmodum. §. magistratus. et $j$ : de sumpt. et ven. c. ulti. ubi de hoc. Et nota, quod secundum canones sive vi sive metu, sive dolo aliquis renunciat rei suae: subvenitur ei ... Quis autem metus excusare possit, patet per hunc versum Hosti. Excusat carcer, status et mors, verbera stuprum. Excusare metus hoc posse puta: quia nescis. Stupri sive status, verberis atque necis. ff. eo. ego puto et 1 . nec timorem et 1 . isti quidem. $\S$ I et II et III. Item metus substantiae suae 'j'. c. proxi. Ber.".

Chyba nie trudno zauważyć, że mamy tu przed sobą jak najdokładniejsze wydobycie ze źródeł prawa rzymskiego i kanonicznego wszystkich przypadków groźby większej. Czyżby do czasów pojawienia się tej glossy nie były one jeszcze znane? Otóż jeżeli idzie o respektowane przez prawo rzymskie, to nie tylko o nich wiedziano i przejęto je do kanonistylki, ale nawet je ujęto już $\mathrm{W}$ mnemotechniczną formulę (Hostiensis). Lecz autorowi tej glossy widocznie chodziło o cośs więcej, mianowicie chciał najpierw wykazać, że do powyższej stereotypowej grupy gróźb powinno się dołączyć jeszcze inne przypadki i to zarówno ze źródeł prawa rzymskiego jak i kanonicznego. Nastepnie dokonał on podziału wszystkich przypadków pod takim kątem patrzenia, że do jednych wymaga 
prawo danej groźby relatywnie największej, a przy drugich zadowala się powołaniem strony przymuszonej na jakąś groźbę relatywnie mniejszą. Która za'ś $z$ tych mniejszych gróźb będzie się nadawała w konkretnym wypadku, dał autor na to pytanie krótką odpowiedź: sprawa ta zależy albo od swobodnego uznania sędziego, albo od postanowienia najwyższej władzy, albo od opinii względnie interpretacji wytrawnego prawnika. Czy ta odpowiedź oparta wyłącznie na źródłach prawa rzymskiego miała być mutatis mutandis przeniesiona do sfery kanonistycznej, tego autor wyraźnie nie powiedział. W każdym bądź razie całą tę glossę należy zakwalifikować jako przełomową, a to ze względu na dokonane przez nią powiększenie zakresu gróźb większych i podzielenie ich na relatywnie większe i relatywnie mniejsze.

Po stwierdzeniu powyższych danych przychødzi nam z kolei stanąc przed pytaniem, do której grupy gróźb zaliczyła glossa bojaźń w przymusie małżeńskim. Pytanie to stawiamy tymbardziej, że przy zawieraniu małżeństwa domagały się prawo rzymskie a jeszcze bardziej kanoniczne, aby konsens małżeński był w szczególności wolny od wszelkiego przymusu. Otóż okazuje się, że $\mathrm{w}$ tej sprawie wypowiedziała się glossa przy sławnym c. $14 \mathrm{XIV}, 1$. Mianowicie po przedstawieniu status quarestionis zapowiedziała ona, że ,glossa sequens distinguit sexum circa metum." Rzeczywiście uczyniła to w następujący sposób: „Metus. Qui possit cadere in constantem virum. ' $j$ '. c. proxi. etc. consultationi. in fina $\S$ ff. quod met. cau. minor tamen metus magis excusat feminam quam virum. arg. XXXII q. VI indignantur et arg. ' $j$ '. de homi. sicut dignum. 'j' infra respons.". Pomijamy, że to ujęcie opiera się na kruchym uzasadnieniu, bo na analogii dwóch źródeł kanonicznego prawa karnego, ale przytaczamy je jako nowość.

Zamykając cały ten rozdział poświęcony glossie do Dekretaliów Grzegorza IX, musimy stwierdzić w końcowym wniosku, iż mimo danych wykazujących wyraźne oderwanie się od dawnego schematu gróźb nie napotkaliśmy $w$ niej nie tylko zaliczenia małżeńskiego metus reverentialis do grupy 
gróźb relatywnie mniejszych, ale i żadnego śladu dyskusji nad tym zagadnieniem.

d) Chyba nie musimy tu wyjaśniać, na czym polegała prawno-historyczna rola średnowiecznych glossatorów, zwłaszcza autorów wyżej omówionych trzech gloss ordynaryjnych. Krótko mówiąc, przypadło im zadanie pierwszego a zarazem zasadniczego rozbudzenia teoretycznych refleksji nad poszczególnymi instytucjami prawnymi, ale - co w tym miejscu podkreślić należy z naciskiem - w ścisłej łączności $z$ dosłownym brzmieniem źródeł. To też, co się tyczy dalszej rozbudowy teorii prawa rzymskiego i kanonicznego oraz nagięcia jej do potrzeb bieżącego życia ustaliło się w nauce przeświadczenie, że ta praca przypadła już postglossatorom i ich następcom.

Z rozmysłu na to ogólne prawno-historyczne zjawisko zwracamy uwagę, bo $\mathrm{w}$ rozpatrywaniu naszego zagadnienia przychodzi teraz kolej właśnie na czasy postglossatorów. Ponieważ niewielkie ramy niniejszego artykułu nie pozwalają na szczegółowy rozbiór wszystkich dzieł komentatorów, ograniczymy się więc do najważniejszych.

Zacznijmy od Goffreda de Trano. ${ }^{27}$ Ponieważ jego Summa in titulos Decratalium pojawiła się przynajmniej o 20 lat przed glossą Bernharda de Botone, więc nie dziw, że omówiony $w$ niej pogląd na wpływ przymusu na akty prawne jest odwzorowaniem tylko zapatrywań dawniejszych $z$ tym jednym dodatkiem, iż wprowadzoną przez Dekretalia Grzegorza IX dodatkową groźbę utraty majątku należy brać w znaczeniu: „Grave autem damnum appello damnum omnium rerum vel maioris partis". Natomiast na baczniejszą uwagę zasługuje $w$ tym dziele fakt, że Goffredus przy omawianiu I tytułu księgi IV Dekrataliów poruszył sprawę przymusu małżeńskiego zawartą $\mathrm{W}$ Celsusowym fragmencie Si patre cogente, a wraz $z$ nią także zagadnienie metus reverentialis. Mianowicie doszedl on na podstawie tego fragmentu do prze-

27 Goffredus Tranensis, Summa in Titulos Decretalium, Venetiis 1564, De his quae vi metusve causa firunt, s. 135-347, 349 . 
świadczenia następującego: „Intellige enim quod pater filium cogere potest modica coatione s. increpatione paterna praecise autem cogere non potest... Sed numquid filia cogetur invita illum in virum ducere ... respondeo ... quod filia patri danti sibi virum contradicere non potest. Subaudio sine vitio ingratitudinis ... et poterit exhereditari ... Sed matrimonium vel sponsalia non tenebunt, nisi consensus filii vel filiae accedat..." Nie jest to oczywiście stanowisko nowe, bo $w$ odniesieniu do syna już przedtym to samo powiedziała glossa ordinaria do C. 2 X q. III, c. IV ad „Patrem”. Przy czym rzecz znamienna, że gidy przyszło mu uzasadniać dlaczego po narzuceniu córce kandydata na męża nie powinna się ona sprzeciwiać, powołał się na jej bojaźń ściągnięcia na siebie zarzutu niewdzięczności, czyli na metus reverentialis. Czyżby autor nie dopuszczał do zaistnienia w podobnej sytuacji takiej samej bojaźni u syna? Trudno coś pewnego na to pytanie odpowiedzieć. W każdym bądź razie idąc po myśli wyżej przytoczonej Akkursiańskiej glossy ad „Maluisse”, należałoby się spodziewać odpowiedzi pozytywnej.

$\mathrm{Z}$ komentarza Joannis Andreae Super quarto decretalium 28 zasługuje na uwage następujący pogląd: ,... metus qui cadit in constantem virum sive fuerit maior sive minor ille cui infert non est matrimonium". Zajęcie takiego stanowiska przez autora nie jest niczym innym, jeno zastosowaniem do przymuszonego małżeństwa jak najszerszego owego zakresu bojaźni, który ustawiła wyżej przytoczona glossa ordinaria.

Bartolus 29: Przy komentowaniu edyktu Quod metus causa (D. 4, 2) ograniczył się tylko do następujących uwag: „Metum. Metus intelligitur qui cadit in constantem virum ut mortis vel crutiatus corporis, vel servitutis, vel pudicitiae, secus

28 Joannis Andreae, Summa de sponsalibus et matrimonio, et de quartum decretalium librum novella decretalia, Venetiis 1581, ad c. 14 (IV, 1).

29 Bartoli Prima super Digesto Veteri, Lugduni 1540, Quod metus causa gestum sit. s. 126 ; B a rtoli Commentaria in primam Codicis partem, Lugduni 1552. De his quae vi metusve causa gesta fiunt s. 95. 
si alterius levis vexationis vel infamiae ... Oppo. quod metus infamiae inducit rescisionem coactus ut. j'. eo. 1 . fi ff. fenerator. Resp. non rescindit per actionem q.m.c. ut hic, sed per officium iudicis, ut ibi. idem si per timorem reverentiae, ut puta filia ob reverentiam patris ... et ideo glos. dicit quod factum metu rescinditur multis modis ..." Szerzej o tych zagadnieniach rozpisał się B. w komentarzu do Kodeksu ad lib. II De transactionibus. 1. (13) Interpositas: ,....quod iustus metus dicitur metus mortis vel cruciatus corporis. 5. Quandoque quis vult rescindere aliquod factum metu ex edicto praetoris quod m. c. et tunc requiritur ille metus, de quo hic loquitur ... Quandoque quis vult rescindere ex sententia edicti et tunc sufficit esse metus in persona filii ... quandoque quis vult rescinidere per officium iudicis et tunc sufficit metus verecundiae ... quandoque infertur metus ratione maioritatis et reverentiae et istud fit dupliciter, nam quaedam est reverentia, vel maioritas, absque potestate publica, ut maioritas quae habetur a marito in uxorem, a patrono in libertum et tunc rescinditur etiam per officium iudicis ... quod tene mente, quia (6.) si uxor facit aliquid propter minas a viro illatas, officio iudicis rescinditur..." Do zagadnienia metus reverentiae powrócil $\mathrm{B}$. jeszcze raz $\mathrm{w}$ tytule De his quae vi metusve przy 1. (6)" Ad invidiam”: „Ex dignitate sola contrahentis violentia non probatur. $h$. d. No. quod ex dignitate sola non praesumitur violentia vel metus. Ratio dicebatur sibi in 1. interpositas ... sed necesse est, quod probantur minae, vel verbera ut j'. 1. prox. et per Inn. ext. de convers. coniug. c. accedens" (c. 17 X III 32) ... (antiqua lectio ad ,invidiam": ,sola dignitas noon est causa inducendi actionem q. m. c. simile no. quod sola reverentia non est causa inducendi actionem q.m.c. nisi metus, vel alius terror interveniat. Ita d. intelligi 1. I $\S$ quae onerandae ff. qua. re. ac. non dat." (D. 44,5 , $1 \S 6)$. Że pogląd Bartolusa na zasadnicze elementy przymuszonych aktów prawnych i ich wzruszalności tkwi swymi korzeniami głęboko w ustaleniach glossae ordinariae Dekretaliów Grzeg.orza IX, tego chyba nie trzéba udowadniać. Jeżeli jednak mimo stwierdzenia tego faktu przytoczyliśmy dosłow- 
nie wypowiedzi Bartolusa, to uczyniliśmy dlatego, aby zwrócić baczniejszą uwagę, iż ten sławny komentator poświęcil w swoich wywodach aż tyle miejsca metui reverentiali. Otóż najpierw wskazał on przypadki, w których z tytułu takiej bojaźni można było wzruszyć dany akt officio iudicis. Następnie podkreślił z naciskiem, że domniemywać się metus reverentialis z samej godności nie można. Aby zaś taka bojaźń miała siłe dowodową, muszą jej towarzyszyć albo minae albo verbera. To zastrzeżenie Bartolusa $w$ tym miejscu ze szczególnym naciskiem podkreślamy jako postulowaną nowość, zwłaszcza że przyjdzie nam na nią się powołać przy dalszym rozwiązywaniu naszego zagadnienia. Ale wszystkie dotychczasowe nasze uwagi o stanowisku Bartolusa w sprawie metus reverentialis nie byłyby zupełne, gdybyśmy pominęli fakt przemilczenia przez niego zagadnienia wpływu bojaźni z tytułu naruszenia czci ojcowskiej na zawarcie małżeństwa przez córkę lub syna. Sądzimy, że Bartolus nie wymienił tego przypadku dlatego, ponieważ nie znalazł w źródłach prawnych żadnego uzasadnienia.

Czego nie dopowiedział Bartolus, powiedział Baldus ${ }^{30}$ : „, Si patre (cogente). Reverentia filii erga patrem matrimonium non infirmat licet alias filius non fuisset contracturus ... Istam legem intellige quando propter reverentiam patris filius consentit, non autem intelligas quod intercesserit verus metus: quia tunc matrimonium esset nullum, ut in l. si mulier. Allegat et hic in ulti. glo. C. eo. nee filium. no. extra quod metus cau. abbas. probatur extra de spons. c. cum locum". Ale zestawiając Baldusa $\mathrm{z}$ Bartolusem musimy zauważyć, że przy zaliczaniu małżeńskiego metus reverentialis do grupy bojaźni niewystarczającej (metus non verus levis) nie zaznaczył, iż tego rođzaju bojaźń w łączności z minae vel verbera stwarza już należytą podstawę prawną do stwierdzenia nieważności danego małżeństwa. W każdym bądź razie $\mathrm{z}$ owego przemilczenia nie należy wyprowadzać wniosku, że ten ko-

30 Baldi Perusini Commentaria in Digestum Vetus, Lugduni 1562. De ritu nuptiarum. Si patre. 
mentator nie uznawal owego zestawienia metus reverentialis z którąś z mniejszych gróźb za wystarczającą podstawę do uznania przymuszonego małżeństwa za nieważne (zob. wyżej J. Andreae). Że w rzeczywistości było wprost przeciwnie, wystarczy powołać się na marginalną notkę dodaną później do glossy ad „Patrem" (C. XX q. c. 4): ,...sed dic quod requiritur quod praecedant minae a patre ut p. Bar. in. 1. interpositas. C. de transact. et no. Cy. et Bal. 1.I Co. de bon. mater."

Co dotyczy Antoniego de Butrio, 31 to spośród jego wywodów tkwiących w glossa ordinaria do Dekretaliów Grzegorza IX zasługuje na podkreślenie: ,...dicit glo. quod in arbitrando metu hoc reliquitur arbitrio iudicis, attenta qualitate personarum et facti ... Attendenda tamen est qualitas personae, quia lenior metus indicabitur cadere in constantem quoad feminam quae ut fragilior, quam quoad hominem ... ubi minorem metum quis est passus, dabitur iudicis officium..."

$\mathrm{Z}$ tego, co $\mathrm{w}$ swoim komentarzu napisał Panormitanus ${ }^{32}$ w sprawie małżeńskiego metus reverentialis należy - zdaniem naszym - podkreślić chyba tylko jedno: Mianowicie według niego tę rolę, którą w prawie rzymskim pełnił fragment Celsusowy Si patre cogente, przypadła w prawie kanonicznym c. 1 X IV, 2 (Tua). Spostrzeżenie to zakończył znamienną uwagą: ,... hodie stamus canonibus non autem legibus, quia materia matrimonialis est canonica et non legalis".

Zamykając powyższą wypowiedzią Panormitanusa poglądy postglossatorów na małżeński metus reverentialis, należy stwierdzić, że w zasadzie obracały się one w ramach ustaleń, których dokonały glossae ordinariae. Mówimy: w zasadzie, ponieważ $\mathrm{w}$ mocnym oparciu o Celsusowy fragment Si patre cogente przez 13-o wieczne glossy wysunięty i skwalifikowany jako levis małzeński metus reverentialis został przez postglossatorów podtrzymany $\mathrm{w}$ całej pełni, zarówno w nauce

31 Anttonius de Butrie, Completus super quinque libris decretalium, Papie 1496. De this que vi metuswe causa.

32 Abbatis Panormitani Commentaria in quartum et quintum librum, Venetiis 1588 , In quartum I c. XIII, III c. 'I.

Prawo Kanoniczne - 17 
prawa rzymskiego jak i kanonicznego. Fakt ten zadziwia nas o tyle, że w tym samym czasie kanonistyka poszerzyła u siebie po prawie rzymskim odziedziczony krąg metus maioris malitatis, a podzieliwszy $w$ tym kręgu groźby na względnie większe i względnie mniejsze tym ostatnim przyznała wpływ na nieskuteczność przymuszonego małżeństwa. Poza tym zasadniczym podtrzymaniem przez postglossatorów stanowiska gloss ordynaryjnych $w$ sprawie małżenskiego metus reverentialis uważamy za wskazane dodać jeszcze jedno spostrzeżenie. Mianowicie ci sami postglossatorzy, gdy szło o przeprowadzenie procesowego dowodu na nieważność przymuszonego małżeństwa nie odrzucali powoływania się na metus reverentialis, ale domagali się, aby tej bojaźni towarzyszyła któraś $z$ dwóch mniejszych gróźb, a więe minae vel verbera.

\section{IV}

Mając przed oczyma wyniki badań, przeprowadzonych nad naszym zagadnieniem $w$ okresie średniowiecza, stajemy tym samym na progu odmiennych już czasów i to zarówno dla prawa rzymskiego jak i kanonicznego. Ze względu na szczupłe ramy tego artykułu wstrzymujemy się od charakterystyki owych czasów i z miejsca przechodzimy do dalszych badań.

Zaczynamy od Didaci Covarroviasa ${ }^{33}$ : Przede wszystkim przejął on od Tomasza z Akwinu pogląd, że ,,constans vir erit qui eliget potius rem ipsam agere, cuius agendae causa periculum quod gravius atque acerbius est viro prudenti, quam ipsam rem agere". Z rozmysłu na ten fakt zwracamy uwage, bo chcemy $\mathrm{w}$ tym miejscu zaznaczyć, że Covarrovias przy określaniu zachowywania się viri constantis w obliczu grożącego mu zła, nie ograniczył się do źródel prawa rzymskiego, jak to dotąd czynili kanoniści, ale sięgnął w tej sprawia jeszcze do ujęcia św. Tomasza. To zjawisko tym bardziej nas zaciekawia, gdy sobie uświadomimy, że zarówno określenie

33 Didacis Covarrovias a Leyva Toletani opera omnia, Francofurti ad Moenum 1608, 140. De metu in matrimonii contractu interveniente. 145 n. $\S$ De Metu. 
rzymskich prawników jak i Tomaszowe pochodzą z tych samych źródel Arystotelesowych. Wie o tym dobrze Covarrovias, bo właśnie przytacza te same miejsca $z$ etyki nikomachejskiej. Powstaje zatem pytanie, co nowego wnieść mogło określenie Tomaszowe. Otớż okazuje się, że gdy rzymskich prawników określenie ograniczało się tylko do wyliczenia przypadków gróźb, pod którymi rozumnemu mężowi można bylo ugiąc się i zastosować do woli grożącej osoby', to Tomaszowe określenie sięgała głębiej, gdyż w ślad za Arystotelesem wskazywało przypadki, w których rozumnemu człowiekowi nie wolno było $z$ punktu widzenia etycznego ugiąc się przed wolą grożącego, choćby za to przyszło zapłacić śmiercią. Zwracając na tę różnicę Tomaszowego określenia naszą uwagę, przez to nie chcemy twierdzić, aby tego nie uwzględniały etyka chrześcijańska i kanonistyka od pierwszych swych czasów. Jeżeli więc Covarrovias powołał się $w$ tym miejscu na św. Tomasza, to tylko chyba dlatego, iż znalazł w jego określeniu viri constantis elementy, których nie zawierało określenie rzymskie.

Ale poza tą nowością spotykamy u Covarroviasa jeszcze drugą, dotycząca bezpośrednio już naszego zagadnienia. Oto ona: "Caeterum, cum de libero consensu agamur, scire oportet, num metus ille qui contingit ex obsequio et reverentia quae praelatis, parentibus et superioribus debetur, matrimonium contractum impediat? Et gl. in c. praesens 20 , c. 4 tenuit non impediri propter istum metum matrimonium carnale, quamvis spirituale, q. in religionis professione contrahitur, impediatur. Primum probat ex 1 . si patre cogente ff. de ritu nup. Secundum per tex. in d. c. praesens clericus 20 q. 4 ciuius glossa distinctionem dicit peragendam ... Ego tamen distincte hoc tractabo, ut expeditior sit huiusce rei intellectus. Primo enim illius gl. assertio probatur in d. 1. patre cogente propter quam idem notat Abbas ... Praepos... Host... et Imo... Sed cum in matrimonio maior sit exigenda libertas, quam in caeteris contractibus, notandum est caeteros contractus non esse rescindentos ex solo metu reverentiali, nisi praecedentibus minis 
illatis ab eo, qui solet qui minatur exequi. Bar. in 1. I $\S$ quae oneranda ff. qua re actio non det. Quamvis gl. ibi indistincte dixerat; contractus ex hoc metu rescindendos esse. Sed intelligenda est uti Bar. eam intellexit, quam sequitur Abbas... Alex... Ias... eandem opinionem sequuntur profitentes esse communem... Eandem intelligunt, nisi enormis laesio in contractibus contingat, cum metu obsequi et reverentiae. Hoc enim solum etiam minis non probatis, sufficiet ad rescindendum contractum, quod eleganter notaverat Aret. con. 24 col. 2. etiamsi iuratus esset contractus... Quae omnia nec temere adduximus, sed ut matrimonii contractus nullus omnino sit, eo casu, quo caeteri contractus ex hoc metu sint rescindendi, q. est ab omnibus receptum. Qua in re non admittenda sententia Jo. Ignei, qui in 1. 3. § eleganter. nu. $176 \mathrm{ff}$. ad Syllania dicebat matrimonium contractum ex solo metu reverentiali nullum esse ac si ex alio metu cadienti in constantem virum esset contractum, pro qua opin. retorquet 1. si patre cogente ff. de ritu nup. dum eo autore lex illa dicit contraxit tamen matrimonium, quod inter invitos contrahitur. Igitur ilius, qui patris reverentia cogente, matrimonium contraxit, non liberum, sed coactum matrimonium contraxisse videtur: quod nullo pacto valet et dum subdit 1. illa, maluiss hoc tamen videtur eam interpretatur, quando filius novo consensu saltem tacito ratum habet matrimonium contractum metumque purgat. Haec idem interpretatio inconcina est, decemptumque opinюr. Jo. Igne. virum alioquin doctissimum, falsa illius legis lectione: Siquidem in Pandectis Florentinis ita textus ille legitur, contraxit tamen matrimonium, quod inter invitos non contrahitur. Atque haec lectio vulgo receptissima est. Nec etiam placet Jo. Ignei opinio, dum adversus communem opinatur, quemlibet actum metu reverentiali gestum, rescindendum fore." Widocznie za czasów Covarroviasa zaczęto ju'z $\mathrm{w}$ kanonistyce poruszać zagadnienie, czy sam metus reverentialis może wystarczyć do stwierdzenia nieważności małżeństwa, jeżeli ten poważny teolog podjął się rozpatrzenia tego pytania aż pod formą osobnej tezy. Niestety, nie udało się nam dotrzeć do wszystkich owych auto- 
rów, których przytoczył choćby sam Covarrovias. Gdy idzie o wartość argumentów, na których autor oparł swoją tezę, to $\mathrm{w}$ pierwszym rzędzie zadziwić nas musi jego pogląd na charakter przymusu $w$ omówionej przez nas wyżej glossie ad „Patrem” c. 4, C. XX q. 4: „Item habes hic, quod timor patris impedit matrimonium spirituale, licet secus videtur in matrimonio carnali, ut ff. de ritu nup. si patre cogente. Sed intellige de levi coactione". Otóż okazuje się, że autor niesłusznie zacieśnił ów przymus ojcowski tylko do metus reverentialis $\mathrm{i} w$ następstwie takiego ujęcia wyprowadził wniosek, iż tylko dlatego małżeństwo w przypadku Celsusowym zostało uznane za zawarte, ponieważ był levis metus reverentialis, natomiast wstąpienie do klasztoru Lamberta uznano za nieważne, ponieważ było dokonane pod naciskiem gravis metus reverentialis. Niewątpliwie Covarrovias dał się zwieść wyrażeniem timor patris, które żadną miarą nie da się pogodzić z tekstem papieskiego dekretału, mówiącym wyraźnie o zaszłym przypadku violentiae ze strony ojca. Inaczej natomiast ma się sprawa $z$ drugim argumentem: „cum in matrimonio maior sit exigenda libertas, quam in caeteris contractibus". Że taki pogląd kiedyś tu i ówdzie w kanonistyce poruszany nie utrzymał się, nie będziemy tego udowadniać. Wystarczy gdy stwierdzimy, że go nie podtrzymywał i Cavarrovias, ale poszedł za powszechnie przyjętym, tj. domagającym się, aby także w tym punkcie nie robiono różnicy między małżeństwem a innymi kontraktami. Wykazawszy na swój sposób, że sam metus reverentialis nie może naruszyć ważności zawartego małżeństwa, zaatakował przeciwne twierdzenie Jo. Igneusza, oparte na zdefektowanym tekście Celsusowego fragmentu Si patre cogente.

Po Covarroviasie, jednym $z$ głównych autorów hiszpańskich (Salmanticences) piszących $\mathrm{w}$ czasie soboru trydenckiego, przechodzimy $z$ kolei do największego na owe czasy dzieła $\mathrm{z}$ zakresu prawa małżeńskiego, mianowicie do Sancheza De sancto matrimonii sacramento (1602). ${ }^{34}$ Rozpatru-

${ }_{34} \mathrm{San}$ chez $\mathrm{T}$., De sancto matrimonii sacramenta disputationum tomi tres, Venetiis 1672. T. I Lib. IV De consensu coactio. 
jąc W księdze IV przymusowy konsens małżeński poświęcił autor oddzielny rozdział (Disputatio VI) naszemu zagadnieniu: „An timor reverentialis censeatur cadens in virum constantem, ad efectum irritandi obligationes voluntarias?"

Zanim przystąpimy do samego zagadnienia, zwróćmy uwagę na następujące wstępne ustalenia Sancheza. Otóż najpierw zaatakował on przez niektórych autorów zaczerpnięty ze św. Tomasza pogląd, że constans vir ma być tym rozumnym człowiekiem, który w przypadku zaistniałej groźby powinien zawsze wybrać działanie jako zło mniejsze w porównaniu z grożącym mu większym. A uczynil to $z$ następującego powodu: ,Sed dicendum est, non satis esse, ut dicatur metus cadens in virum constantem, ut vir illud malum constanter caveat, sed debere esse timorem gravis mali in se considerati ... Et ratio aperta est, quia iura concedunt rescissionem contractus ob timorem cadentem in virum constantem: quia is timor libertatem consensus impedit ... sed quando malum quod timetur, in se ipso leve est, quamvis graviori malo anteponatur, non impedit in viro forti libertatem consensus". Następne ustalenia dotyczą: ,ut timens non vane leviterque credat malum illud sibi imminere, sed probabiliter et rationabiliter"; ,sed esse timorem probabilem proximae illationis"; ,ut metum incutiens potens sit minas executioni mandare ... minas exequi solitus sit"; "metum cadentem in virum constantem dici respective et proinde metum, qui respectu unius est cadens in virum constantem non esse talem respectu alterius, qui fortior et robustior est: unde minor metus desideratur in foemina, quam in viro ... non tantum in foemina respectu viri, sed etiam inter ipsos viros ... attendenda est aetas ... similiter eius fortitudo, innataque animi magnitudo, aut parvitas et fragilitas".

Po tych wstępnych ustaleniach przejdźmy do samego zagadnienia, które Sanches ujął w formę, ,de sufficientia huius timoris (reverentialis) ad rescindenidos contractus, et annulandum matrimonium".

Autor zacząl swoje wywosy od stwierdzenia: „Quadruplex igitur est sententia, I. ait, metum reverentialem cadere in 
virum constantem, atque ita rescindere alios contractus et consequenter matrimonium tali metu initum esse nullum. Probat ex regul. Velle $4 \mathrm{ff}$. de regul. iur ibi, velle non creditur, qui obsequitur imperio patris vel domini: ergo cum omnis contractus consensu perficiatur, rescindet, illos metus obsequii, seu reverentiae. 2. probatur ex $1.1 \S$ Quae oneranda ff. quarum rerum actio, ibi, et hoc causa cognita, si liquido appareat libertum metu solo, vel nimia patroni reverentia, ita se subiecisse ... et confirm. quia si tantum metus reverentialis rescinderet contractus, ubi interveniunt minae, nulla esset prorsus differentia inter metum eius cui debetur reverentia et metum cuius cumq. extranei, cum quocumc. grave malum minenti, quod potest et solet exequi, si metus viri constantis. Quare frusta DD. contorquerentur tractantes de metu reverentiali..." II. Sententia ait, metum reverentialem patris esse cadentem in virum constantem, sufficereque ad contractum rescissionem, non autem metum similem aliorum, quibus reverentia debetur. Nec aliam differentiae huius rationem assignat, quam esse nimiam reverentiam debitam patri ... III. Sententia ait, contractum initum cum eo, cui debetur reverentia, vel ad eius utilitatem, rescindi ob metum reverentialem, secus cum alio ... Ultima sententia (quam multo veriorem reputo) docet solum metum reverentialem, nisi minae aut verbera, aut alius metus gravis illi adiungatur, non cadere in virum constantem, ac prinde nec annullare matrimonium, nec alios contractus rescindere. Probatur ea sola ratione quia metus reverentialis non videtur tantam vim habere ad cogendum voluntatem, ut vir constans eo terreri debeat. Quare potissima probatio ex aliquibus textibus accipienda est. Probatur ergo primo ex cap. Ex literis de despons. impub. ibi nolens et invita minis parentum impulsa: ubi textus quo reddet irrita sponsalia metu reverentiali parentum inita, ponderat non solum paternam reverentiam, sed simul minas. Secundo probatur ex cap. 2 de pactis in 6 ubi dicitur valere renuntiationem filiae, in favorem patris factam, si iuramento muniatur, nisi vi et dolo sit praestitum: et tamen ibi concurrit paterna reverentia: 
ergo ea sola non inducit vim aut metum. Tertio probatur ex variis textibus quibus probabitur ... professionem non annulari ex solo metu reverentiae: iidem enim probant idem de matrimonio, cum ... idem metus in utorque casu requiratur: immo secundum multos ... minor sufficiat ad annullandam professionem. Quarto probatur ex l. Si patre cogente, $22 \mathrm{ff}$. de ritu nup ... ubi glossa finalis ait: maluisse hoc videtur, quam odium patris incurrere, non autem dicas metum adhibitum: ergo solus metus reverentialis non satis est..."

Tak w skrócie wyglądają owe przez Sancheza zestawione cztery sentencje $w$ sprawie, czy sam metus reverentialis moze zaczepić ważność małżeństwa. Każda $z$ tych sentencji powoluje się na teksty prawnicze, każda $z$ tych sentencji ma swoich zwolenników. Najwięcej oczywiście sentencja czwarta. I nie dziw, wszak ona reprezentuje pogląd najstarszy i powszechnie przyjęty. Niestety, gdy idzie o wymiar siły dowodowej źródeł prawa rzymskiego i kanonicznego, jest on rozmaity n.p. pierwsza sentencja zaczęła swoje uzasadnienie od D 50, 17, 4: Ulpianus libro sexto ad Sabinum. Velle non creditur, qui obsequiter imperio patris vel domini. Że tak daleko sięgającego wniosku $z$ tej reguły nie należy wyprowadzać, wykazał Beseler. Co się zaś tyczy innych źródeł rzymskich, powołanych przez Sancheza we wszystkich czterech sentencjach, nie będziemy tu przeprowadzać szczególowej analizy, a powiemy tylko, że poza fragmentem Celsusowym Si patre cogente reszta ma tylko siłę analogii $i$ to przeważnie dalekiej. Nie ma dwóch zdań, że każda $z$ nich przemawia raczej za tezą, iż sam metus reverentialis bez dołączonej groźby większej nie może zaczepić wzgł̨̨dnie unieważnić danego aktu prawnego. To samo należy powiedzieć i o źródłach prawa kanonicznego, $\mathrm{z}$ tą tylko różnicą, gdy rzymskie prawo wyraźnie nie dopuszczało do zaistnienia gravis metus reverentialis, to kanoniczne tej możliwości w swojej teorii gróźb większych nie wykluczało.

Nasze uwagi o zajętym stanowisku Sancheza w sprawie naszego zagadnienia nie byłyby zupełne, gdybyśmy pominęli 
jego dwa spostrzeżenia wypowiedziane w końcowej części sentencji czwartej: In aliquo tamen casu, attentis particularibus circumstantiis occurrentibus posset admitti ea opinio, nempe si cum metu reverentiali concurrat filium esse valde paternis praeceptis obtemperantem, et mulierem valde imbecillem ... Tunc enim si ... pater praecipiat ... filio, ut contractum celebret in ipsius praecipientis utilitatem, est metus sufficiens ad rescindendum contractum. Ut optime admittunt. Suarez ... Matienzo ... Gutier ... Garcia ... Salzedo ... B. Diaz; Immo censetur metus viri corstantis, sine minis, si is cui reverentia debetur, nimis crudelis sit, et saevitiam prae se ferat, solitusque saevire fit, ubi suae non obtemperatur voluntati. Quia quamvis minae actu desint, sunt tamen virtute estque probabilis timor proximae coactionis. Zapewne owe dwa spostrzeżenia można - jak to zrobił Sanchez - połączyć $z$ sentencją czwartą, ale tak samo dobrze można je zaliczyć na rachunek sentencji pierwszej, zakładającej możliwość zaistnienia gravis metus reverentialis. W każdym bądź razie należy stwierdzić, że Sanchez w swoim sławnym dziele o małżeństwie mimo opowiedzenia się za sentencją czwartą dal początek także sentencji nowej.

$\mathrm{Na}$ zakończenie celem uniknięcia nieporozumień przytoczymy z Sancheza następujace uściślenie prawnicze metus reverentialis: Maxime tamen advertere oportet, quis dicatur metus reverentialis: Non enim sufficit metus et verecundia quae naturaliter inest filiis coram patre... Sed tunc id eveniet, quando ea reverentia in metum inducit et causa fuit, ut filius consentiret, timens non offendere patrem... et non audens illi contradicere ... Quando talis metus est causa principalis actus, vel contractus, ita ut eo non intercedente nullo modo actus vel contractus fieret. Quod adhuc sic ego explico: Non enim credo sat esse, ut actus alio modo non fieret: nam plurima sunt intercessione parentum ... at libentissimo animo ea facit filius ... nec dicendum est haec omnia esse involuntaria ... sed tunc hoc evenit, quando omnino repugnanti voluntate, et quasi coactus consentit, non audens prae puidore 
et reverentia contradicere, quamvis nullum aliud malum timeat (Disp. IX n. 12).

Wobec tak na owe czasy wszechstronnego rozpatrzenia naszego zagadnienia przez Sancheza staje się dla nas rzeczą zrozumiałą prawno-historyczny fakt, dlaczego 'następne pokolenia badaczy ciągle się odwoływały do rozwiązań Sanchezowych. I tak skądinąd ze swej samodzielności znany de Lugo ${ }^{35} \mathrm{~W}$ tym punkcie prawie że dosłownie. Inaczej Pontius ${ }^{36}$ : Secundo colligitur, eum qui ob observantiam debitam parentibus, aut maioribus aliquid agat, nequaquam operavi ex reverentiali metu. Aliud enim est debita reverentia superiori, aliud reverentialis metus... Quod reipsa non attendit, sed confundit Th. Sanchez disp. 6, citat. q. 1. Quare recte potest aliquis operari ex reverentia, et non ex metu reverentiae: et similiter potest operari non ex superioris praecepto, et obedientia, sed ex metu. Haec enim non sunt idem. Si filius amet obedire parenti, et complaceat in obediendo illi nullum est involuntarium, et tamen operatur ex reverentia, metus autem efficit involuntarium mixtum. Quare, ut metus reverentialis sit, necesse est adsit cogitatio imminentis mali, quod sequitur et timetur ex eo, quod non servetur patri reverentia. Quod in eo consistit, quod est patrem habere sibi infensum et superciliosum, torne aspicientem, nec loquentem placide, etiamsi nec verba imponat, nec minetur. Quod ut vi vitiet malum, eligit praestare quod pater vult, metus enim, ut dixi, est cum impendentis mali cogitatione. Si eo ingenio superior vel pater sit ut non offendatur ex eo, quod ipsi non praestetur obedientia, aut leviter offendatur, non fore metum gravem nec enim potest esse cogitatio impendentis gravis mali quod vitare velit, dum eligit facere, quod pater iubet ... Praeterea certum est, si metu reverentiali addantur minae vel preces, vel verba obiurgatoria, ex his duobus coalescere gravem metum, idque docent Doctores omnes ... Mihi tamen semper

35 De iustitia et iure, Lugduni 1646, T. II Disp. XXII, Sect. VII, n. 150 .

30 Ponti i, B.,De Sacramento matrimonii tractatus, Venetiis 1645, Lib. IV, cap. V. n. $1-13$. 
verius visum est solum metum reverentialem esse gravem, atque ideo in actibus et contractibus eum effectum habere, quem metus gravis. Addo praeterea in hanc sententiam manifesto incidere Th. San. qui nostram accriter impugnat, vel non intellexit, de quo quaestio esset, sed nomine metus reverentialis intellexit reverentiam parentibus debitam. ... Est ergo patris ira et indignatio, quam evitare contendit. Indignationis autem nomine intelligitur totus aspectus, vultus intensus, exprobratio verbis durioribus. Haec autem si cito transeant et placidus statim vultus et dulcia verba redeant, grave malum non est ... Nec verbo dici potest eam.

Engel, ${ }^{37}$ opowiedziawszy się za poglądem Sancheza, że sam metus reverentialis przy unieważnianiu małżeństwa nie może być uznany za wystarczający, przyznaje jednak, iż nie jest wykluczony przypadek zaistnienia i takiej bojaźni. A mianowicie: Sin autem praeter reverentiam alia insuper adminicula concurrant, ex quibus colligi possit, aliquem revera fuisse invitum, ut inaequalitas contrahentium, periculosae minae, importunae persuasiones, et ut verbo dicam, si modesta contradictio nihil iuvisset, tunc metus reverentialis etiam pro iusto metu habendus erit. Vid. Rota apud Farinac. in decis. crim. et test. decis. 242. Podobne stanowisko zajął także Pirhing 38: Similiter praeces importunae ac saepius repetitae, etsi non solae coniunctae tamen cum metu reverentiali personae rogantis et moleste instantis, inferunt metum cadentem in virum constantem, ideoque sufficientem ad infirmandum matrimonium ... Ratio est, quia difficillimum est, diuturnas preces Superioris reicere semper, quod citra periculum gravissimae offensionis fieri vix potest. Do przytoczonego przez Sancheza zarzutu, poco nauka zajmuje się lekkim metus reverentialis, jeżeli do jego skuteczności wymaga się dołącze-

37 Collegium universi iuris canonici, Salisburgi 1688, Lj'b. IV, Tit. I $\S \mathrm{V}$ n. 4.

38 Pirhing, Ius canonicum, Dilingae 1678, Tom IV, Lib. IV, Tit. I, Sect. IV \& V. 
nia jakiejś groźby większej, nawiązuje Kugler ${ }^{39}$ i tłumaczy w ten sposób: Nam quamvis etiam minae valdi gravis mali sufficerent ... si sint a persona atroci et quae solet eas exequi ... nihilominus minores sufficiunt, si illae coniungatur cum metu reverentiali, quia solae ab extraneo intentatae non sufficerent.

W nawiązaniu zaś do powyższych przypadków, które Sanchez przytoczył - formalnie należących do lekkiego metus reverentialis, a merytorycznie do ciężkiego - pozwolimy sobie przytoczyć wypowiedzi dwóch autorów: Schmalzgruebera ${ }^{40}$ : invalidum esse matrimonium ... contractum a Virgine cum Iuvene, quem illa aversabatur, ex mera reverentia in parentes, cum indignationis, exprobrationum, curae tractationis et similium incommodorum verissimili existimatione coniuncta; Lehmkuhla ${ }^{41}$ : Licet ille metus (reverentialis) per se non pro gravi habeatur, si tamen pro ingenio personae vel pro adiunctis aliae causae timendi accesserunt, pro gravi non difficulter habetur potissimum in muliere. Generatim autem ille metus reverentialis, cui accedunt preces multum importunae, pro gravi habetur. Że powyższy pogląd $w$ nauce utrzymał się aż do dzisiejszych czasów, wystarczy przytoczyć, co Capello 42 zamieścil w swym dziele De Matrimonio Cap. VIII, Art. V. n. 604: Disputant AA. num metus reverentialis sit levis aut gravis. Per se est levis, quia confusio et molestia, quam patitur inferior ob solam offensionem et indignationem superioris, non constituit de se malum grave. At si huiusmodi offensio et indignatio sit gravis vel in se ipsa vel ex adiunctis, puta si accedant iurgia, rixae, preces importunae

${ }^{39} \mathrm{Kugl}$ er, Tractatus de Matrimonio, 1713, q. XXXVII n. 670 n.

40 Sichmalzgrueber F., Matrimonium seu Decretalium Gregorii IX Liber quartus, Constantiae 1715, T. I, Sect. IIT $\S$ II. De impedimento vis et metus n. 384.

41 L e h m k h 1, Theologia moralis, $1892^{9}$, Voil. II. P. II. L. I. Tr. De matrimonio, 525 .

42 Capello F., De Sacramentis, Vol. III, De Matrimonio, Romae $1927{ }^{2}$. Zob. Noldin H., Summa theologiae moralis, Vol. I. De Principiis, Oeniponte $1956^{13}, 56-58$; Vol. III, De Sacramentis, Oeniponte $1955^{31}, 539$. 
(scil. instantes et diuturnae), quaerimoniae etc., metus censetur gravis. Si denique timetur notabile damnum, ex. gr. exhaereditatio, expulsio, aut verberationes vel minae atsint, tunc est metus gravis simpliciter. Qua distinctione optime conciliari possunt DD., quorum alii metum reverentialem habent gravem alii levem. Sane huc quoque spectat generale principium: metus oritur ex malo, quod quis sibi imminere existimat; si ergo ex indignatione parentum vel superiorum imminet aut imminere potest malum grave, metus reverentialis erit aut esse poterit gravis.

Po prawno-historycznym przebadaniu teoretycznych poglądów na nasze zagadnienie przychodzi kolej na ustosunkowanie się do tych poglądów sądów duchownych.

Nie mamy tu zamiaru przeprowadzać ścisłej statystyki wniesionych i rozstrzyganych spraw małżenskich $z$ tytułu metus reverentialis. Stwierdzimy tylko, że na przestrzeni czasu od XV w. do dzisiaj spotykamy powolne ale za to stałe narastanie owych spraw $w$ najwyższych dykasteriach kościelnych. Zjawisko to świadczyłoby nie tyle, zdaniem naszym, o nasileniu tego rodzaju przypadków $\mathrm{w}$ życiu, ile o toczonej w tym okresie ciągle narastające j dyskuisji naid naszym zagadnieniem. Spróbujmy sięgnąć po dowody. Otóż, co się tyczy sławnego zbioru Thesaurus resolutionum S. C. Concilii, to w jego rozlicznych tomach natknęliśmy się zaledwie na 12 przypadków. Jeżeli w pierwszym $z$ nich (t. 41 str. 232) spotykamy panujący jeszcze pogląd: Communis tamen invaluit opinio, solum metum reverentialem per se gravem non esse, nisi alia concurrant scilicet imperii coactio, minae, durae tractationes et huius generis alia, to w 93 tomie (1833) juz natrafiamy wymóg lagodniejszy, bo: matris et tutoris suasiones quando sunt importunae ob debitam reverentiam iustum metum invehunt et coactionis vim habent in liberi consensus exclusione. Dla czasów ostatnich są źródłem Sacrae Romanae Rotae Decisiones seu sententiae. Dla przykładu wystarczy przytoczyć następujące poglądy (in iure): Vol. XXXVI (1944). Dec. VIII: Metus autem per se levis est; eius veruntamen gravitas directe arguitur ex modis asperis, ex impor- 
tunis precibus ataque ex dispotica impositione, indirecte autem ex aversione vel repugnatione metum passi. Dec. XII: metus vero reverentialis, ad effectum irritandi matrimonium, per se est levis, quia magis ab intrinseco quam ab extrinseco provenit; unde per se solus non habet vim irritandi consensum, nisi reverentiae aliquid aliud accedat, velut altera impulsio et tunc metus reverentialis dicitur qualificatus. Dec. XVIII: Obiectum specificum timoris reverentialis est in'dignatio parentum, quae si praevidetur gravis est diuturna fore gravem metum filio incutere potest. Vol. XXXVII (1945), Dec. LIV: Tamen iuxta iurisprudentiam constanter receptam imperiosa et aspera verba, diuturnae atque importunae suasiones, imo et preces assidue repetitae de proposito matrimonio contrahendo, cum timore reverentiali coniunctae etiam sine minis et verberibus, constituunt metum cadentem in virum constantem, efficacem ad infirmandum matrimonium.

Zamykając całokształt przeprowadzonych badań nad naszym zagadnieniem, pozwolimy sobie $\mathrm{z}$ nich wysunąc $\mathrm{w}$ tym miejscu następujące wnioski końcowe:

Co się tyczy zawartego pod przymusem małżeństwa rzymskiego, to przy dochodzeniu jego nieważności metus reverentialis nie odegrał żadnej roli, i to zarówno w czasie, kiedy samo zawarcie małżeństwa należało do sfery metaiurydycznej, jak i po wciągnięciu go do sfery prawnej. Tego właśnie rodzaju stan rzeczy należy tłumaczyć jedynie specyfiką gróźb przewidzianych przez prawo rzymskie przy rozrywaniu względnie unieważnianiu przymuszonych aktów prawnych. Postawionej za'ś przez kilku badaczy hipotezy, że w Celsusowym fragmencie Si patre cogente należy się dopatrywać metus reverentialis, a więc dla małżeństwa rzymskiego rzekomo utworzonego wyjątku od powyższej specyfiki gróźb, żadną miarą nie da się utrzymać $i$ to ani z punktu widzenia autentycznego tekstu tego fragmentu, ani tez tekstu interpolowanego przez Justyniańskich kompilatorów. W każdym bo- 
wiem razie to pewne, że dokonana przez owych kompilatorów przemiana zawartego $\mathrm{W}$ autentycznym tekście znaczenia słów patre cogente $w$ sensie każdego ciężkiego przymusu ojcowskiego na każdy lekki nie była skierowana na zacieśnienie zakresu tego lekkiego tylko wyłącznie do ojcowskiego metus reverentialis.

Powyższy stosunek prawny do metus reverentialis, zdaniem naszym, przetrwał bez zmian aż do polowy wieku XIII pomimo faktu, że rozrastające się w tym właśnie okresie prawo kanoniczne zaczęło już sięgać do poszerzenia sprecyzowanej przez prawo rzymskie specyfiki skutecznej bojaźni większej (metus maioris malitatis) nawet przez przypadki, które wyraźnie zostały przez jurystów rzymskich wyłączone. Powiedzieliśmy: do połowy wieku XIII, bo mamy na myśli Akkurzjańską glosse ido fragmentu Celsusowego Si patre cogente, która w tym źródle dopatrzyła się lekkiego małżeńskiego metus reverentialis (odium patris). Ten prawno-historyczny fakt celowo tu podkreślamy, bo on to właśnie zapoczątkowal $w$ średniowiecznej nauce prawa rzymskiego i kanonicznego dyskusję nad zagadnieniem lekkiego metus reverentialis $w$ ogóle, a małżeńskieg.o $\mathrm{w}$ szczególności. Zjawisko to o tyle nas $\mathrm{w}$ tym miejscu zadziwia, że dotąd ani prawo rzymskie ani kanoniczne lekkiej bojaźni nie przyznawało żadnego znaczenia. Przez to nie chcemy twierdzić, aby $z$ samym lekkim metus reverentialis łączono $z$ początku jakąś zdecydowaną skuteczność prawną, gdyż dyskutujący na ten temat $z$ miejsca zażądali do zaistnienia pełnej skuteczności jeszcze do łączenia którejś z większych gróźb, przynajmniej relatywnie mniejszych (minae vel verbera). Gdy z czasem ustalił się zwyczaj uzasadniania poglądów byle jakimś źródłem prawnym i $\mathrm{w}$ związku z tym - zwłaszcza przy braku wszelkich źródeł przeszedł w myśl glossy ordynaryjnej do Dekretałów Grzegorza IX punkt ciężkości powoływania się na opinię ważniejszych autorów oraz na praktykę sądową, zrozumiemy, dlaczego dyskusja nad tym zagadnieniem małżeńskiego metus reverentialis nie tylko $w$ stosunku do lekkiej bojaźni ojcow- 
skiej wzrosła, ale zaczęła się także poszerzać o pytanie, czy tego rodzaju bojaźń nie mogłaby sama (ex se) wystarczyć do unieważnienia małżeństwa. Nie przesądzamy, ale kto wie, czy do zaistnienia tego zjawiska nie przyczyniły sie poglądy hiszpańskiej grupy teologów - Salmaticenses z okresu soboru Trydenckiego, którzy do dyskusji nad naszym zagadnienie zaczęli wciągać prócz kryteriów prawniczych także moralne i psychologiczne (Etyka Aryst. - Tomasz z Akwinu). Stąd nie dziwimy się, że po tych czasach mógl Sanchez w swoim wielkim dziele o małżeństwie przedstawić aż cztery W obiegu będące sentencje na temat wystarczalności małżeńskiego metus reverentialis. Wprawdzie on sam przychylił się na stronę od dawna $w$ nauce $i \mathrm{w}$ praktyce zobowiązującego poglądu, ale równocześnie zapoczątkował możliwość zaistnienia $w$ pew'nych okolicznościach ciężkiego małżeńskiego metus reverentialis. $\mathrm{Te}$ właśnie możliwość podchwyciły $z$ zapałem następne pokolenia teoretyków i praktyków aż do ostatnich pokoleń włącznie. Że więc lekki metus reverentialis w zakresie prawa malżeńskiego został podniesiony do rangi potencjalnej bojaźni ciężkiej, to tylko dzieło i zasługa tych pokolen; przy braku należytych źródeł prawa kanonicznego nie dało się więcej pro foro externo dokonać. 